\title{
Article \\ Geomechanical Behaviour of Uncemented Expanded Polystyrene (EPS) Beads-Clayey Soil Mixtures as Lightweight Fill
}

\author{
Pouyan Abbasimaedeh ${ }^{1}\left(\mathbb{D}\right.$, Ali Ghanbari ${ }^{2} \mathbb{D}$, Brendan C. $\mathrm{O}^{\prime} \mathrm{Kelly}^{3, * \mathbb{D}}$, Mohsen Tavanafar $^{2}$ and $^{2}$ \\ Kourosh Ghaffari Irdmoosa 4 \\ 1 Independent Researcher, Melbourne 3000, Australia; p.abbasi84@gmail.com \\ 2 Faculty of Engineering, Kharazmi University, Tehran 15719-14911, Iran; ghanbari.khu@gmail.com (A.G.); \\ mohsen.tavana@ymail.com (M.T.) \\ 3 Department of Civil, Structural and Environmental Engineering, Trinity College Dublin, \\ D02 PN40 Dublin, Ireland \\ 4 Iran Construction Engineering Organization, Central Council, Tehran 19947-76517, Iran; \\ kurosch2002@yahoo.com \\ * Correspondence: bokelly@tcd.ie; Tel.: +353-(0)189-623-87
}

Citation: Abbasimaedeh, P.; Ghanbari, A.; O'Kelly, B.C.; Tavanafar, M.; Irdmoosa, K.G. Geomechanical Behaviour of Uncemented Expanded Polystyrene (EPS) Beads-Clayey Soil Mixtures as Lightweight Fill. Geotechnics 2021, 1, 38-58. https:/ /doi.org/10.3390/geotechnics1010003

Academic Editor: Yoshihisa Miyata

Received: 11 March 2021

Accepted: 26 April 2021

Published: 28 April 2021

Publisher's Note: MDPI stays neutral with regard to jurisdictional claims in published maps and institutional affiliations.

Copyright: (c) 2021 by the authors. Licensee MDPI, Basel, Switzerland. This article is an open access article distributed under the terms and conditions of the Creative Commons Attribution (CC BY) license (https:/ / creativecommons.org/licenses/by/ $4.0 /)$.

\begin{abstract}
Lightweight fill can be advantageous in embankment construction for the purposes of reducing the (i) bearing pressures on the underlying soil foundation, (ii) destabilizing moments for constructed earthen slopes, and (iii) earth pressures acting behind retaining walls. This paper investigates the merits/limitations of particulate expanded polystyrene (EPS) beads mixed with clayey sand (CS) soil as lightweight fill, considering both geotechnical and environmental perspectives. The bench-scale geotechnical testing programme included standard Proctor (SP) compaction, California bearing ratio (CBR), direct shear (sheardox), oedometer and permeability testing performed on two different gradation CS soils amended with $0.5,1.5$ and 3.0 wt.\% EPS, investigating two nominal bead sizes equivalent to poorly-graded medium and coarse sands. Compared to the unamended soils, the compacted dry density substantially decreased with increasing EPS beads content, from $2.09 \mathrm{t} / \mathrm{m}^{3}$ (0 wt.\% EPS) to as low as $0.33 \mathrm{t} / \mathrm{m}^{3}$ for $3 \mathrm{wt} . \%$ (73 v.\%) of larger-sized EPS beads. However, from analyses of the test results for the investigated 50 to $400 \mathrm{kPa}$ applied stress range, even $0.5 \mathrm{wt} . \%$ (21 v.\%) EPS beads caused a substantial mechanical failure, with a drastic decay of the CBR and compressibility parameters for the studied CS soils. Given the more detrimental environmental cost of leaving myriads of separate EPS beads mixed forever among the soil, it is concluded that the approach of adding particulate EPS beads to soils for producing uncemented lightened fill should not be employed in geotechnical engineering practice.
\end{abstract}

Keywords: compaction; compressibility; expanded polystyrene; EPS beads; geofoam; lightened fill; strength

\section{Introduction}

A considerable share of the costs of building and infrastructure constructions depends on the geomechanical properties of the underlying soil deposits and the required foundation types. Major problems, including inadequate bearing capacity, excessive subsidence or earth pressures next to structures, liquefaction potential and slope instability issues, adversely impact on financial costs, construction completion time and hazard risks in projects; as an example, a new highway flyover requiring approach embankments bearing on weak soil deposits, as well as face slopes and/or earth-retaining wall constructions. In this regard, utilizing lightened fill solutions reduces (i) bearing pressures acting on the embankment foundation, (ii) destabilizing moments for constructed earthen slopes that could otherwise have potential slope instability issues, and (iii) earth pressures acting be- 
hind retaining walls. Accordingly, construction costs can be reduced, project performance enhanced, as well as achieving environmental benefit effects [1-4].

Lightweight construction/fill materials include expanded polystyrene (EPS) block geofoam [5,6], and soil blends incorporating various lightweight additives (e.g., tire-derived aggregate [7-10], wood chips, and mineral pumice). Applications for the former in transportation infrastructure include, for instance, bridge foundations supported by EPS-block geofoam embankments founded on soft soil [11], protecting buried pipelines and culverts [12] and reducing seismic excitations to soil-steel bridges [13]. For the latter (soil blends incorporating lightweight additives), it is known that the type, aspect ratio and content of these additives have important roles in the mechanical properties of the mixtures. For given compaction moisture content and compactive effort, the density of the lightened fill can be effectively controlled by the amount of lightweight additive used in making the fill. As a construction material, the unique feature that distinguishes EPS from conventional geomaterials is its very low bulk unit weight. Note that utilizing lightweight fill of unit weight less than that of water at locations below the groundwater table level creates a buoyancy effect, which, depending on the circumstances and the applied load magnitude, may impair or enhance geotechnical performance; e.g., for low applied/self-weight loading scenarios, generated buoyancy by a significant volume of submerged EPS-block geofoam may lead to flotation (failure). Conversely, prototype EPS-block footings [14] and bamboo-frame structures incorporating recycled plastic block inclusions [15] have been advocated as foundation systems for lightweight structures bearing on waterlogged peat deposits- these being designed as floating foundations using the weight compensation technique [15].

Compared to EPS-block geofoam, Deng and Xiao [16] and Edinçliler and Özer [17] investigated the geomechanical behaviour/properties of EPS beads-sand mixtures (termed EPS-sand). For instance, Deng and Xiao [16] investigated in proportions 0.5, 1.5 and $2.5 \mathrm{wt}$ \%, with optimum EPS beads content (i.e., the one reasonably balancing the unit weight, strength, and deformation properties) reported in the order of $0.5 \mathrm{wt} . \%$. Liu et al. [18] investigated EPS beads-soil-cement mixtures, with shear strength and stiffness controlled by adjusting the amount of cement used (these increased considerably for cement to soil ratio of 10 to $15 \mathrm{wt} . \%$ ). Satoh et al. [19], Tsuchida et al. [20], and Yoonz et al. [21] investigated EPS beads-dredged soil/clay-cement mixtures for coastal construction projects. Rocco [22] studied clay mixed with up to $1.5 \mathrm{wt}$ \% EPS beads, including investigation of the low-strain dynamic properties (shear modulus and damping), with shear stiffness decreasing with increasing EPS content, but material damping being relatively unaffected by EPS content. With limits on EPS content, these studies indicate that for quick operations and applications not demanding high shear strength, the soil-EPS beads mixtures with/without a binder material may be suitable as lightweight fill.

Compared to uncemented EPS sand $[16,17]$ or clay mixtures [22], the present laboratory study investigates utilizing 0.5 to $1.5 \mathrm{wt}$.\% particulate EPS beads as partial replacement for clayey sand and their effects on the resulting geomechanical and hydraulic behaviour/properties. As described in this paper, a comprehensive testing programme was undertaken, including standard Proctor (SP) compaction, direct shear (shearbox), California bearing ratio (CBR), oedometer and falling-head permeability tests, investigating two particulate EPS materials with different nominal bead sizes. Although some of these tests are well-known for their limitations, they nevertheless provide indications of relative changes in the performance arising from the EPS beads addition. The experimental results are assessed and discussed from a geotechnical viewpoint to establish whether the approach of blending significant volumes of EPS beads with clayey-sand soil for producing uncemented lightened fill merits further research attention. Note that EPS-block geofoam material was not investigated in this study. A discussion then follows concerning the heavy environmental cost of this solution - that is, whereas EPS-block geofoam is alienable from the soil and hence recyclable, pressed separate EPS beads remain forever among the soil matrix for the EPS-sand/clay lightweight fill solution, while EPS beads can also be swept 
away during on-site mixing and construction processes [19]. As described later in the paper, this has far-reaching environmental consequences that have not been considered adequately in previous geotechnical investigations of EPS-sand/clay mixtures.

\section{Experimental Testing Programme}

\subsection{Materials}

Two sand-clay mixtures (soils 1 and 2) were investigated, with their grading curves presented in Figure 1 and some of their physical properties reported in Table 1. Soils 1 and 2 were comprised of $16 \%$ and $31 \%$ fines fractions $(<0.075-\mathrm{mm}$ sized), respectively, with a liquid limit of $32 \%$, plastic limit of $19 \%$, giving a plasticity index of $13 \%$, and plotting above the A-Line on the Casagrande plasticity chart. The coefficients of uniformity $\left(C_{U}=D_{60} / D_{10}\right)$ and curvature $\left(C_{Z}=D_{30}{ }^{2} / D_{60} \times D_{10}\right)$ values are reported in Table 1. Both materials are classified as clayey sand (SC) according to the Unified Soil Classification System.

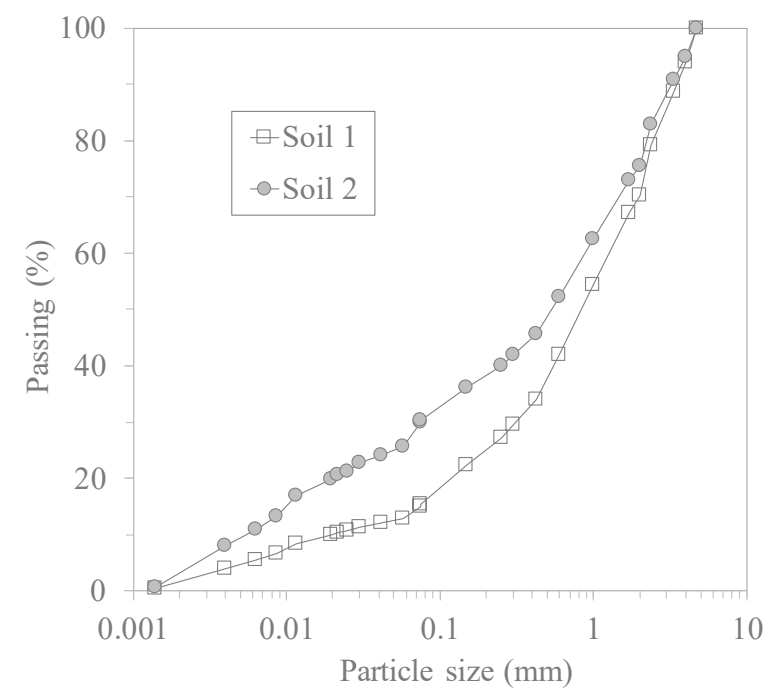

Figure 1. Grading curves for investigated clayey-sand soils.

Table 1. Some physical properties of the clayey-sand soils.

\begin{tabular}{cccccccc}
\hline Material & $\begin{array}{c}\boldsymbol{D}_{\mathbf{1 0}} \\
(\mathbf{m m})\end{array}$ & $\begin{array}{c}\boldsymbol{D}_{\mathbf{3 0}} \\
(\mathbf{m m})\end{array}$ & $\begin{array}{c}\boldsymbol{D}_{\mathbf{5 0}} \\
\mathbf{( m m )}\end{array}$ & $\begin{array}{c}\boldsymbol{D}_{\mathbf{6 0}} \\
(\mathbf{m m})\end{array}$ & $\boldsymbol{C}_{\mathbf{U}}$ & $\boldsymbol{C}_{\mathbf{Z}}$ & $G_{\mathbf{s}}$ \\
\hline Soil 1 & 0.020 & 0.31 & 0.52 & 0.90 & 45 & 240 & 2.66 \\
\hline Soil 2 & 0.005 & 0.07 & 0.82 & 1.20 & 5.3 & 0.8 & 2.66 \\
\hline
\end{tabular}

Two particulate EPS materials (EPS-1 and EPS-2) obtained from Faraz-Foam factory (Shahriar Road, Tehran province, Iran) were investigated; these were distinguished from each other by their different nominal bead sizes (see Figures 2 and 3); that is, EPS- 1 and EPS-2 are equivalent to poorly-graded medium and coarse sands, respectively. Some physical properties of these EPS materials are reported in Table 2. As previously adopted by Deng and Xiao [16], the ASTM C128 standard [23] was employed to determine the grain size and dry special unit weights $\left(\gamma_{\mathrm{dmin}}\right.$ and $\left.\gamma_{\mathrm{dmax}}\right)$ of these EPS materials. 


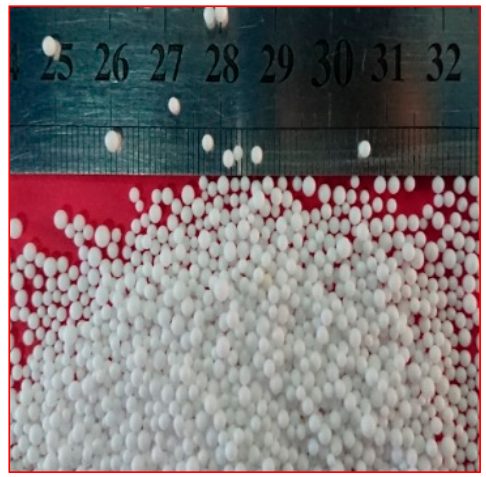

(a) EPS-1.

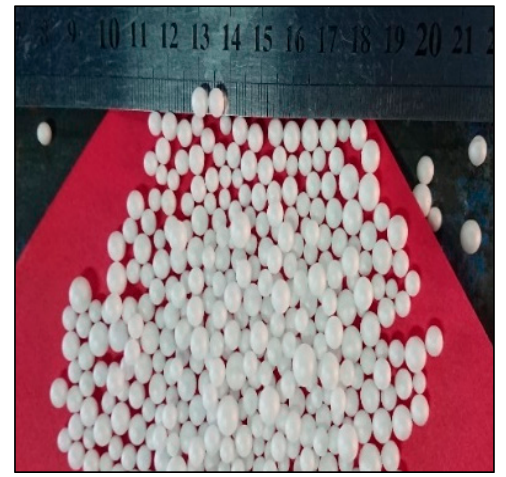

(b) EPS-2.

Figure 2. Spherical EPS beads investigated.

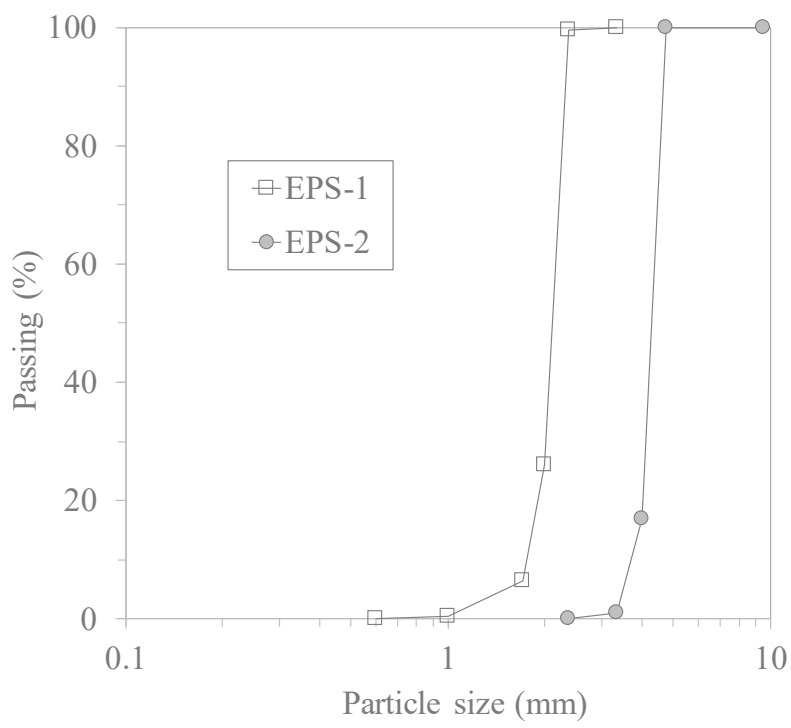

Figure 3. Grading curves for investigated EPS beads materials.

Table 2. Some physical properties of investigated EPS beads materials.

\begin{tabular}{|c|c|c|c|c|c|c|c|c|}
\hline Material & $\begin{array}{c}D_{10} \\
(\mathrm{~mm})\end{array}$ & $\begin{array}{c}D_{30} \\
(\mathrm{~mm})\end{array}$ & $\begin{array}{c}D_{60} \\
(\mathrm{~mm})\end{array}$ & $c_{\mathrm{U}}$ & $C_{\mathrm{Z}}$ & $G_{\mathrm{s}(\mathrm{EPS})}$ & $\underset{\left(\mathrm{kN} / \mathrm{m}^{3}\right)}{\gamma_{\mathrm{dmin}}}$ & $\underset{\left(\mathrm{kN} / \mathrm{m}^{3}\right)}{\gamma_{\mathrm{dmax}}}$ \\
\hline EPS-1 & 1.75 & 2.02 & 2.17 & 1.24 & 1.07 & 0.05 & 0.25 & 0.26 \\
\hline EPS-2 & 3.72 & 4.18 & 4.39 & 1.18 & 1.04 & 0.03 & 0.09 & 0.10 \\
\hline
\end{tabular}

\subsection{Soil-EPS Beads Mixing Ratio and Test-Specimen Preparation}

Dry soil-EPS mixtures were prepared using 0.5, 1.5 and $3.0 \mathrm{wt}$.\% EPS for the two EPS bead nominal sizes, i.e., similar to the 0.5 to $2.5 \mathrm{wt}$ \% EPS range investigated by Deng and Xiao (2010) for sand-EPS beads mixtures. In other words, the testing programme for the present investigation considered 12 soil-EPS beads mixtures and the two controls (soils 1 and 2). In preparing each mixture, the required proportion of EPS beads was added and thoroughly mixed with the disaggregated air-dried soil $(w / w)$ using a mechanical mixer, after which the required compaction water content for specimen preparation was added 
while continuing the mixing process. The EPS beads volumes ( $\chi$, in v.\%) reported for the different mixtures in Table 3 were computed using the following equation [16]:

$$
\chi=\frac{\frac{\eta}{G_{\mathrm{s}(\mathrm{EPS})}}}{\frac{1}{G_{\mathrm{s}}}+\frac{\eta}{100 G_{\mathrm{s}(\mathrm{EPS})}}}
$$

where $\eta=$ wt.\% EPS in -soil-EPS beads mixture; $G_{\mathrm{s}}$ and $G_{\mathrm{S}(\mathrm{EPS})}=$ specific gravity of soil solids and EPS beads, respectively.

Table 3. Volume of EPS beads in various clayey sand-EPS mixtures investigated.

\begin{tabular}{cc}
\hline Mixture & EPS (v.\%) \\
\hline Soils 1 and 2 with 0.5 wt.\% EPS-1 & 21 \\
Soils 1 and 2 with 1.5 wt.\% EPS-1 & 44 \\
Soils 1 and 2 with 3.0 wt.\% EPS-1 & 61 \\
Soils 1 and 2 with 0.5 wt.\% EPS-2 & 31 \\
Soils 1 and 2 with 1.5 wt.\% EPS-2 & 57 \\
Soils 1 and 2 with 3.0 wt.\% EPS-2 & 73 \\
\hline
\end{tabular}

As evident from Table 3, the volume percentage of EPS beads in the various mixtures was substantial, at between 21 and $73 \mathrm{v} . \%$, and depended on EPS bead size, with greater volume proportions for larger-sized EPS beads (i.e., EPS-2) on account of their lower $G_{\text {S(EPS) }}$ value of 0.03 .

\subsection{Experimental Methods}

The experimental testing programme investigating the effects of soil gradation, EPS content and nominal bead size for the various soil-EPS mixtures using standard laboratory tests, including SP compaction [24], CBR [25], direct shear [26] and oedometer [27] testing methods.

The direct shear tests, performed on water inundated $100 \times 100-\mathrm{mm}$ cross-section and initially $30-\mathrm{mm}$ high specimens, involved a consolidation stage, investigating applied normal stresses of $\sigma_{\mathrm{v}}=50,100$ and $150 \mathrm{kPa}$. At the end of the consolidation stage, the inundated specimens were assumed to be fully saturated. Following the ASTM D3080 [26] recommendation that a shearbox horizontal displacement equivalent to $10 \%$ of the test-specimen size should take $60 \mathrm{~min}$, a displacement rate for the shearing stage of $0.217 \mathrm{~mm} / \mathrm{min}$ was adopted, deemed as sufficiently slow to achieve the drained shearing condition.

The oedometer tests, performed on water-inundated 50-mm-diameter and initially 20-mm-high specimens, involved four maintained-load stages at $\sigma_{\mathrm{v}}=50,100,200$ and $400 \mathrm{kPa}$, each of 24-h duration. The permeability characteristics of the various saturated mixtures were determined using the falling-head method, testing 100-mm-diameter $x$ 110-mm long SP-compacted specimens. The falling-head approach was deemed better suited than the constant-head approach given the very low permeability coefficient (order of $10^{-7} \mathrm{~m} / \mathrm{s}$ ) on account of the soils' high fines content. Figures 4 and 5 show images of the soil-EPS beads mixtures and the prepared test specimens. 

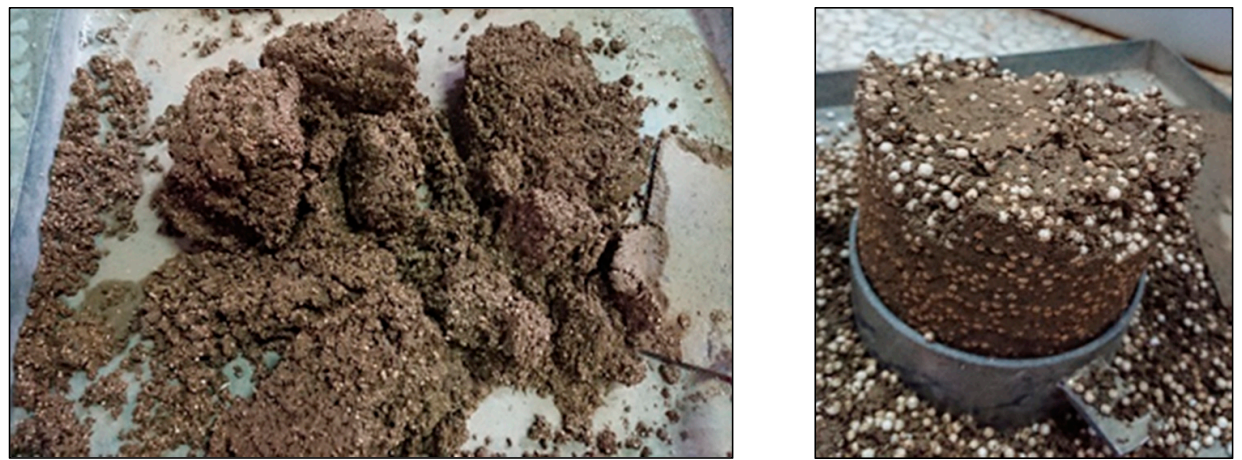

Figure 4. EPS-1 (left) and EPS-2 (right) beads mixed with clayey sand.
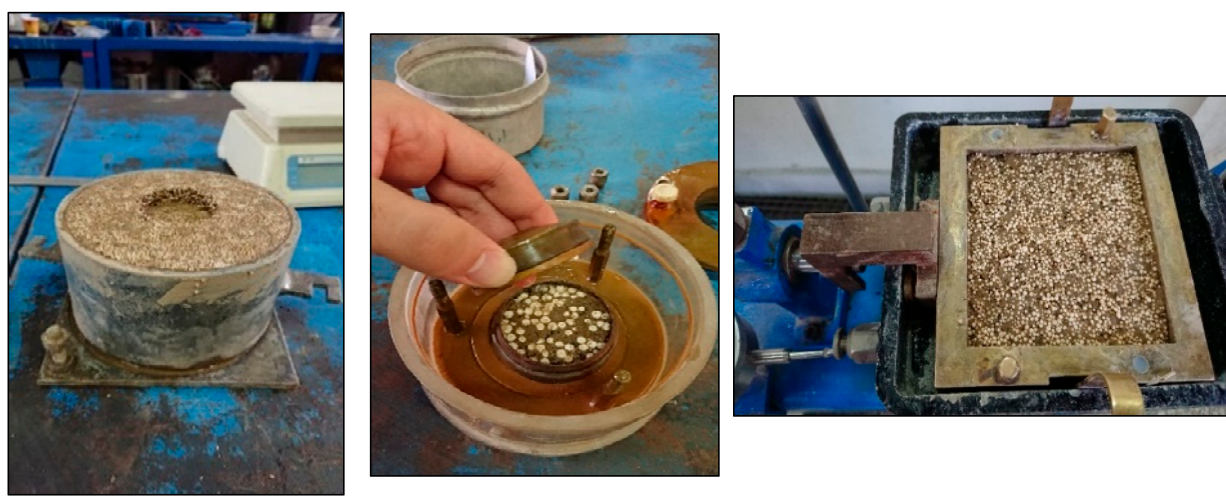

Figure 5. CBR (left), oedometer (centre), and shearbox (right) soil-EPS beads test-specimens.

\section{Experimental Results and Analysis}

\subsection{SP Compaction}

Figure 6 presents the dry density $\left(\rho_{\mathrm{d}}\right)$ against moisture content $(w)$ curves obtained from SP compaction testing of the two controls (soils 1 and 2) and various clayey sand-EPS beads mixtures. The controls had similar experimental $\rho_{\mathrm{d}}-w$ curves, with SP-compacted maximum dry density of $\rho_{\mathrm{dmax}}=2.09 \mathrm{t} / \mathrm{m}^{3}$ obtained at $10 \%$ moisture content. As depicted in this figure, for increasing EPS content, the compaction curves shift downwards, the translation being more pronounced for larger-sized EPS beads mixed with finer gradation soil (i.e., soil 2-EPS-2 combination (Figure $6 \mathrm{~b}$ ), such that the $\rho_{\mathrm{d}}-w$ curves become progressively flatter and clear peaks are not as evident for these mixtures. For instance, SP compaction of the mixture comprising soil 2 with $3 \mathrm{wt} . \%$ of larger-sized EPS beads produced $\rho_{\mathrm{d}} \approx 0.33 \mathrm{t} / \mathrm{m}^{3}$.

\subsection{CBR Results}

Figure 7 plots CBR against EPS beads content for the SP-compacted specimens. As expected, because of its coarser gradation, soil 1, and hence, the soil 1-EPS-1 mixtures mobilized significantly greater CBR resistance compared to soil 2 and the soil 2-EPS-2 mixtures, respectively. Compared to the controls, substantial decreases in CBR magnitude occurred for $0.5 \mathrm{wt} . \%$ EPS, with further CBR reductions occurring for the higher EPS contents. For instance, compared to the control $(C B R=27.5)$, of the mixtures investigated, the best performing in terms of greatest mobilized CBR was the soil 1-0.5 wt.\% EPS-1 mixture (3.7), whereas the soil 2-0.5 wt.\% EPS-2 mixture mobilized a CBR value of only 1.0. 


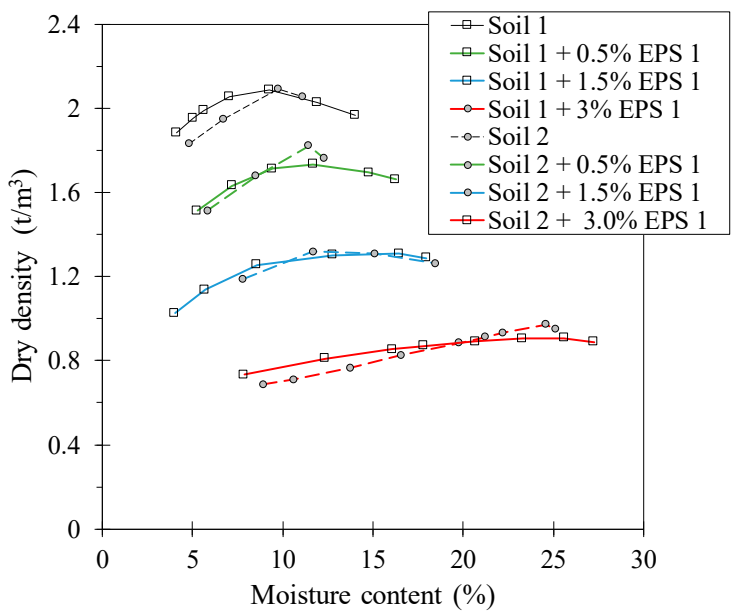

(a) EPS-1 additive.

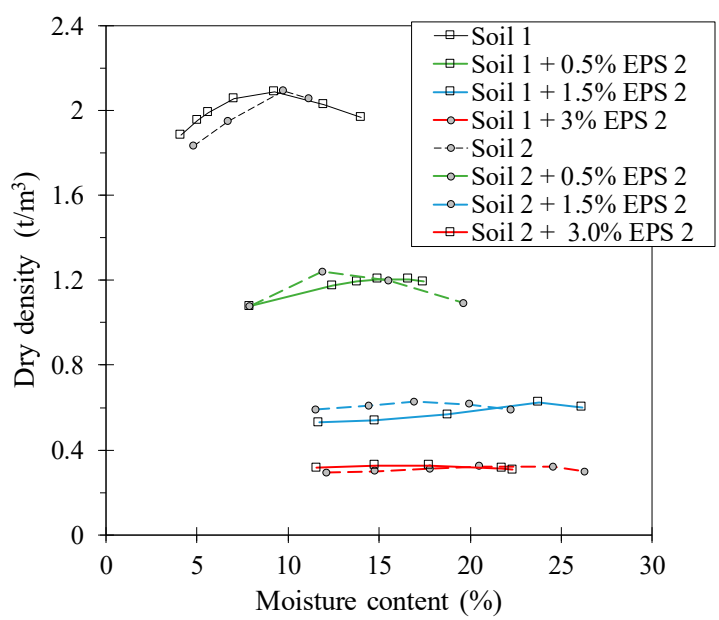

(b) EPS-2 additive.

Figure 6. SP-compaction curves for clayey sand-EPS beads mixtures.

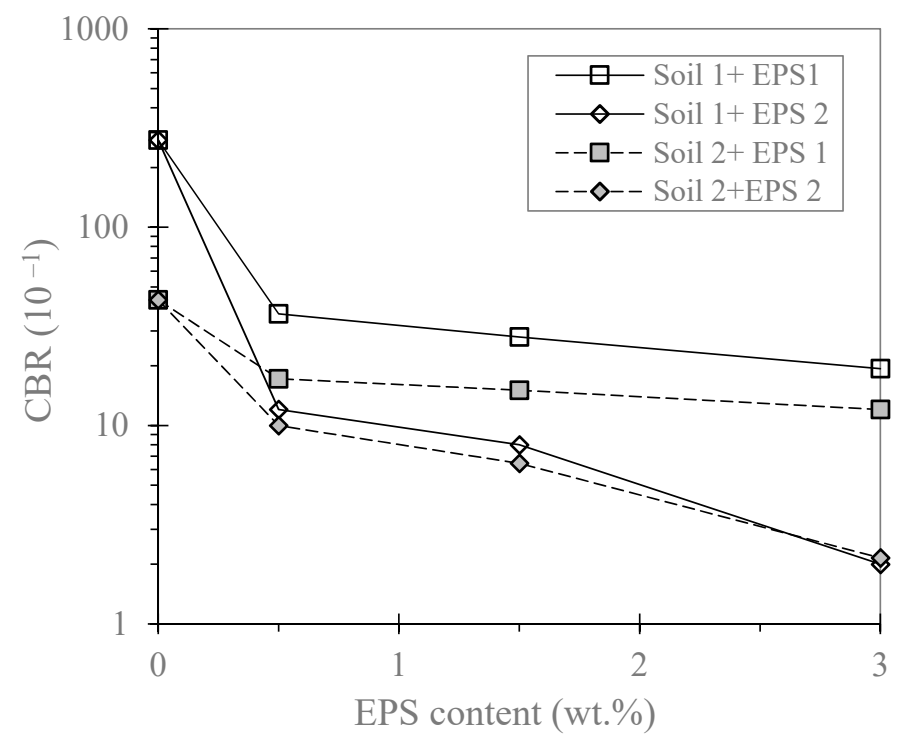

Figure 7. CBR results for clayey sand-EPS beads mixtures investigated.

\subsection{Direct Shear Results}

Figures 8-12 present the direct-shear test results. Figure 8 shows the equilibrium axial specimen compression achieved for normal stresses of $\sigma_{\mathrm{v}}=50,100$ and $150 \mathrm{kPa}$ applied during the specimen consolidation stage. As evident from this figure, due to the highly compressible/deformable nature of the EPS beads, the equilibrium axial compression increases for greater EPS content and for higher applied stress, with significantly greater compression occurring for those mixtures containing larger-sized EPS beads (EPS-2). In other words, compared to EPS-1, the embedded larger-sized EPS-2 beads are drastically compressed and also the soil particles penetrate into them under the high applied stress. For instance, considering the applied stress of $\sigma_{\mathrm{v}}=150 \mathrm{kPa}$, compared to the SP-compacted soils 1 and 2 mixed with 1.5 and $3.0 \mathrm{wt}$ \% EPS-1 (axial strain of $\sim 10.7 \%$ ), these soils mixed with the same wt.\% of EPS-2 beads experienced axial strains of up to $40 \%$. 


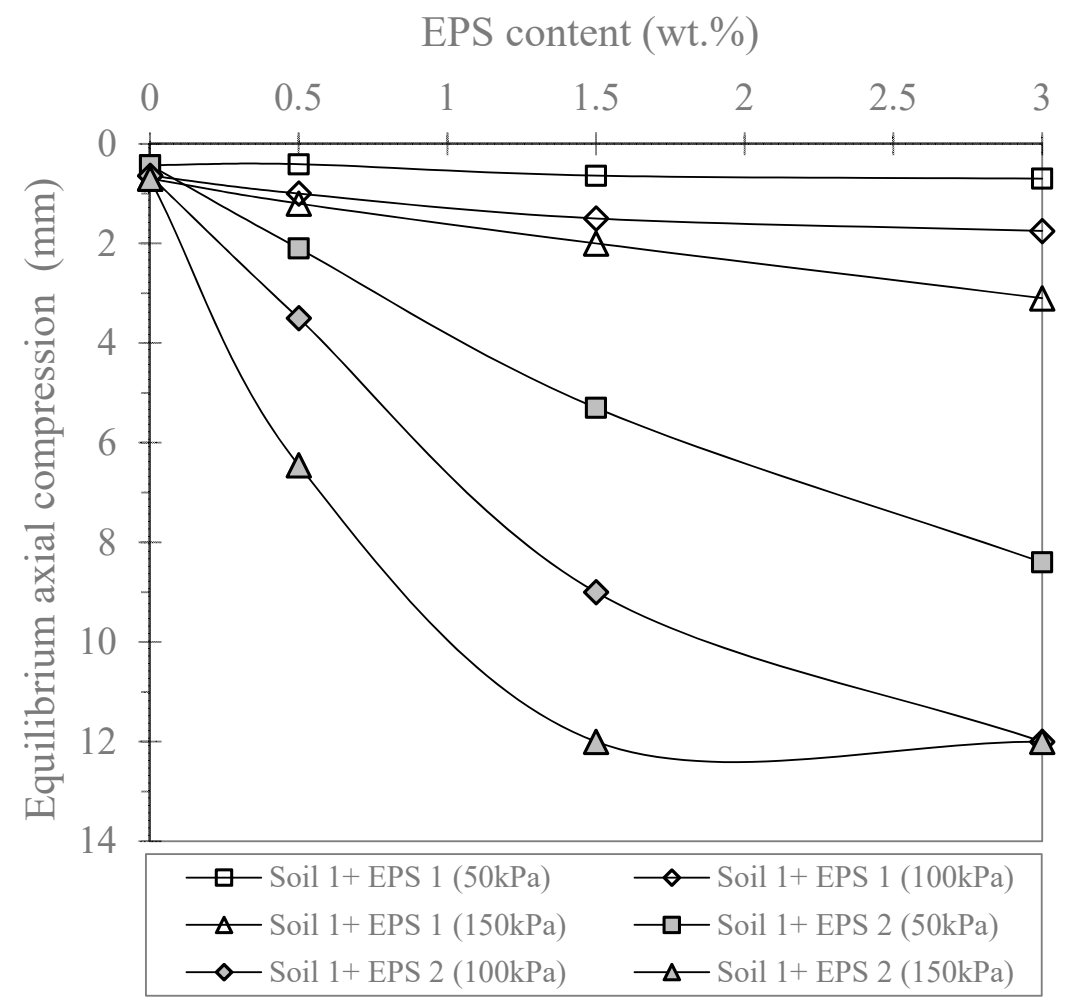

(a) Soil 1-EPS beads mixtures.

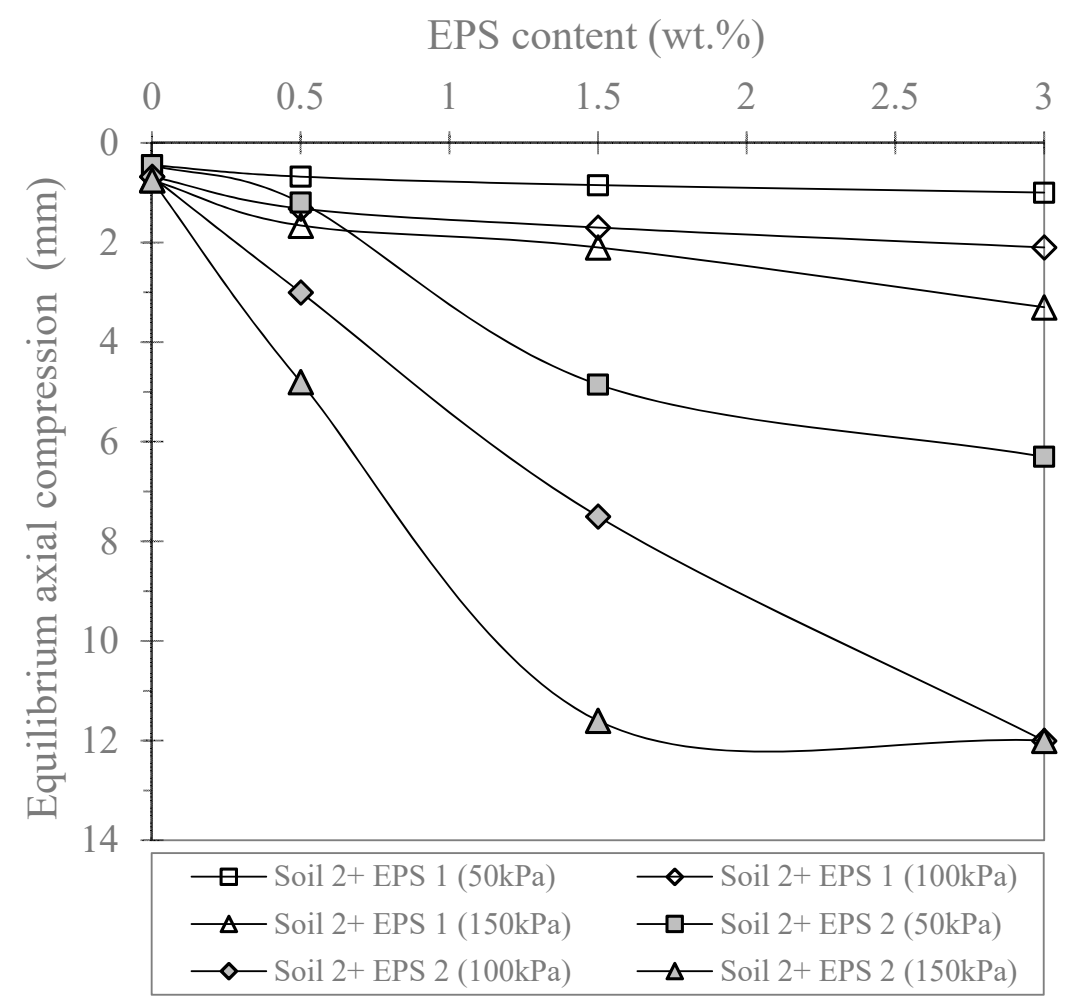

(b) Soil 2-EPS beads mixtures.

Figure 8. Equilibrium axial compression of shearbox specimens for normal stresses of $\sigma_{\mathrm{v}}=50,100$ and $150 \mathrm{kPa}$ applied during consolidation stage. 
Figures 9-12 show the shear resistance against horizontal displacement traces obtained for the various clayey sand-EPS beads mixtures. As evident from these figures, for a given normal stress magnitude, 0.5 to $3.0 \mathrm{wt}$.\% EPS content generally causes a marginal overall reduction in initial specimen stiffness, a substantial reduction in secant stiffness, and a more modest decrease in the peak shear resistance.

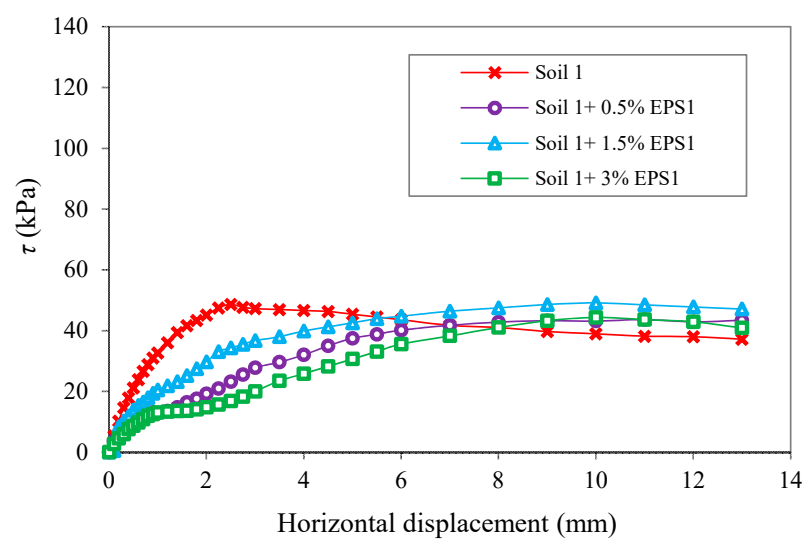

(a) $\sigma_{\mathrm{v}}=50 \mathrm{kPa}$

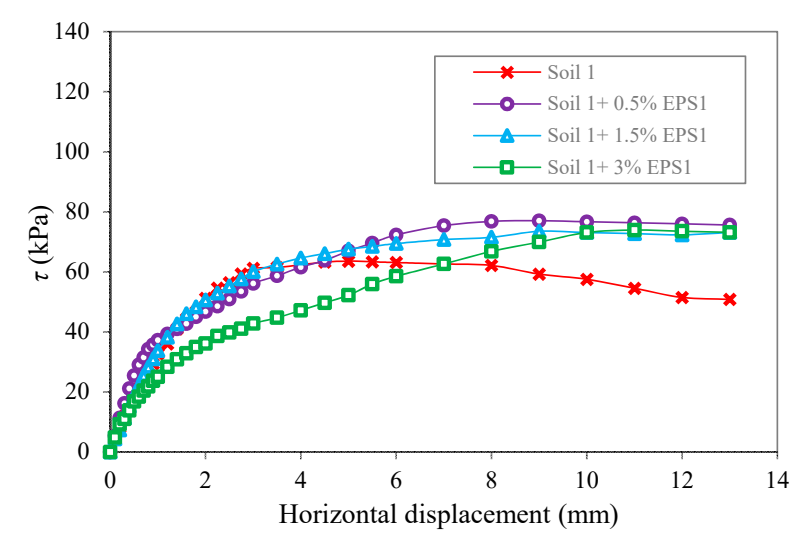

(b) $\sigma_{\mathrm{v}}=100 \mathrm{kPa}$

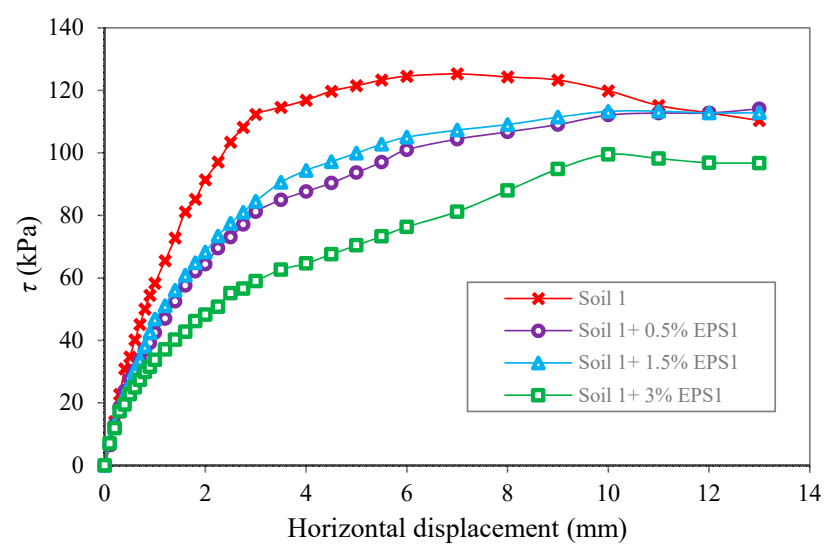

(c) $\sigma_{\mathrm{v}}=150 \mathrm{kPa}$

Figure 9. Shear resistance against horizontal displacement for soil 1-EPS-1 beads mixtures from shearbox tests.

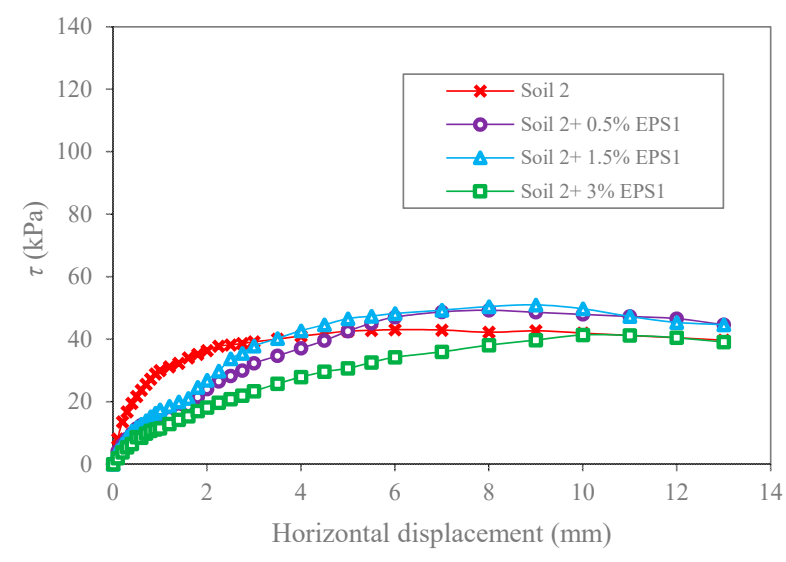

(a) $\sigma_{\mathrm{v}}=50 \mathrm{kPa}$

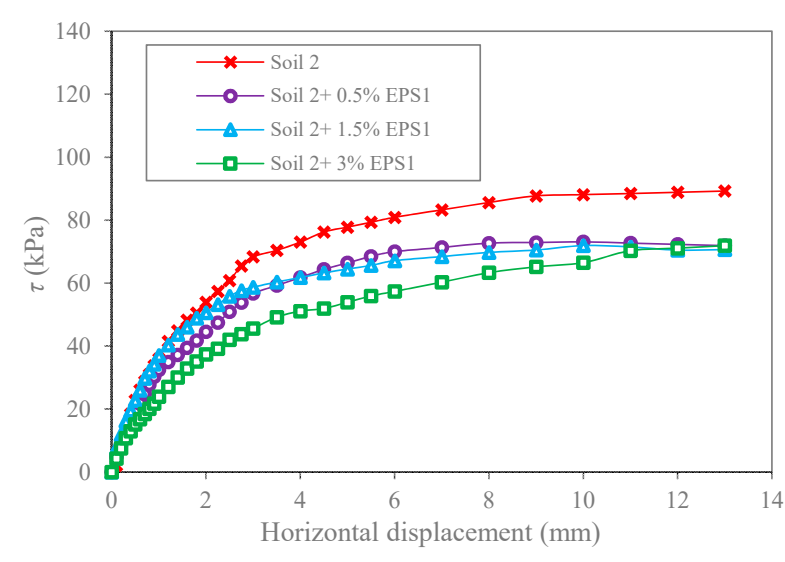

(b) $\sigma_{\mathrm{v}}=100 \mathrm{kPa}$

Figure 10. Cont. 


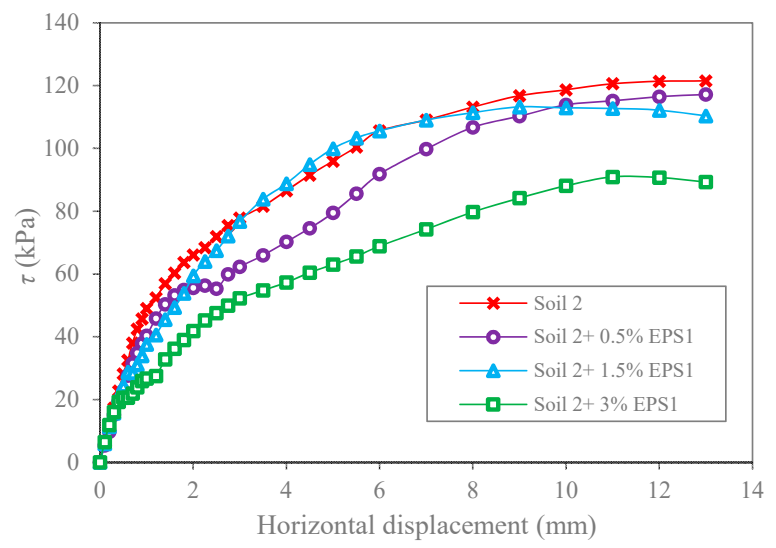

(c) $\sigma_{\mathrm{v}}=150 \mathrm{kPa}$

Figure 10. Shear resistance against horizontal displacement for soil 2-EPS-1 beads mixtures from shearbox tests.

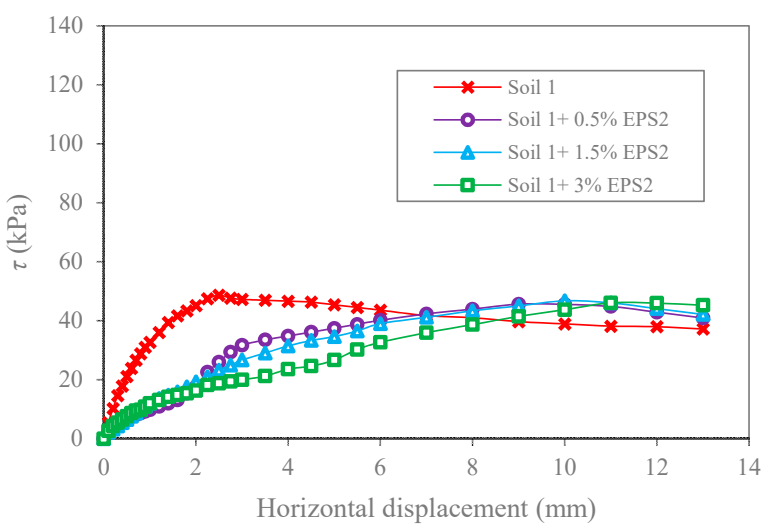

(a) $\sigma_{\mathrm{v}}=50 \mathrm{kPa}$

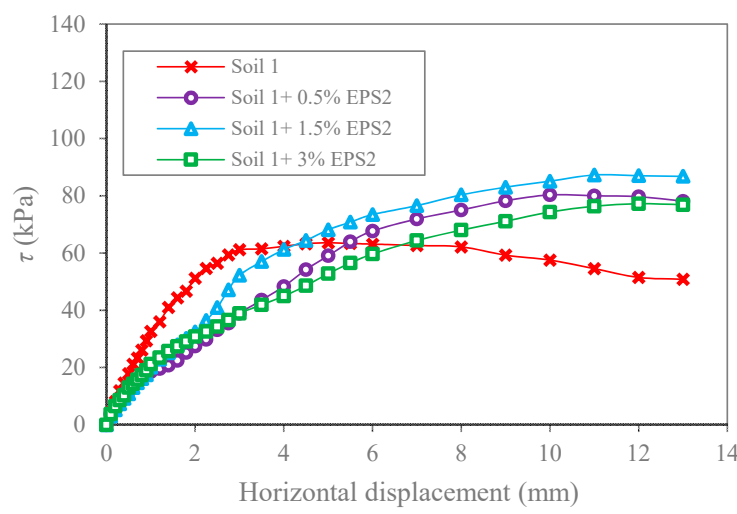

(b) $\sigma_{\mathrm{v}}=100 \mathrm{kPa}$

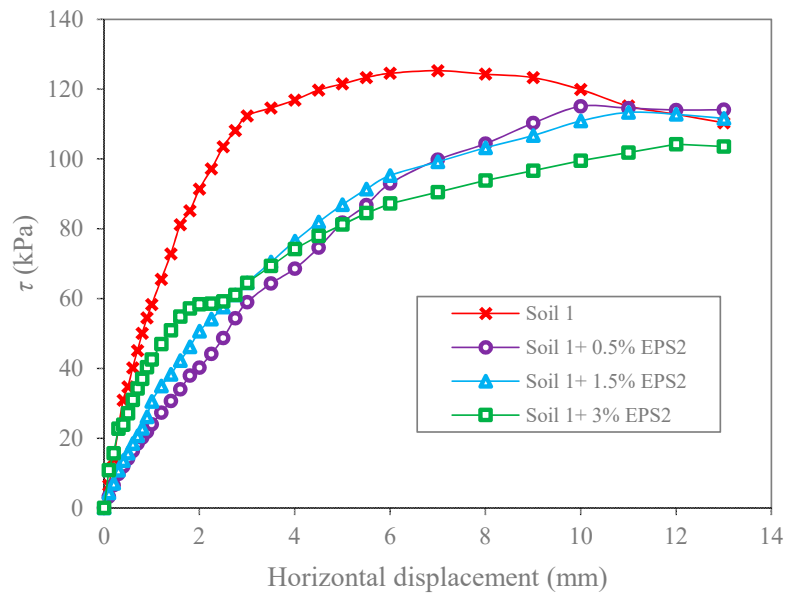

(c) $\sigma_{\mathrm{v}}=150 \mathrm{kPa}$

Figure 11. Shear resistance against horizontal displacement for soil 1-EPS-2 beads mixtures from shearbox tests. 


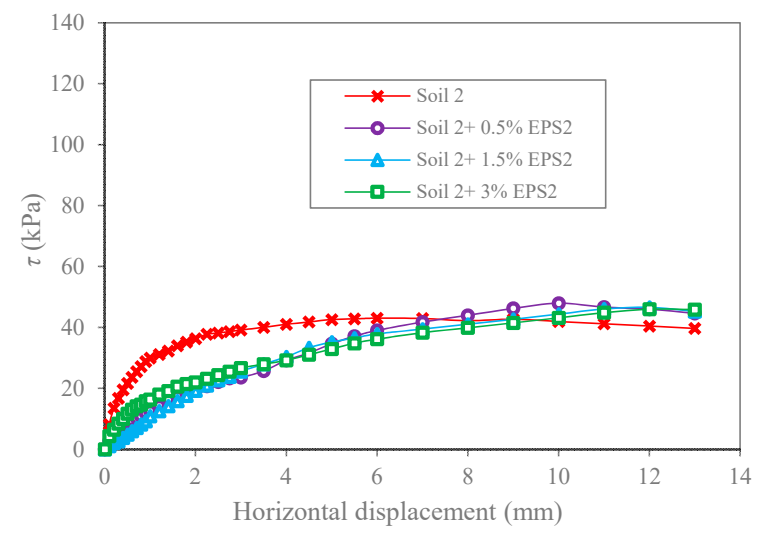

(a) $\sigma_{\mathrm{v}}=50 \mathrm{kPa}$

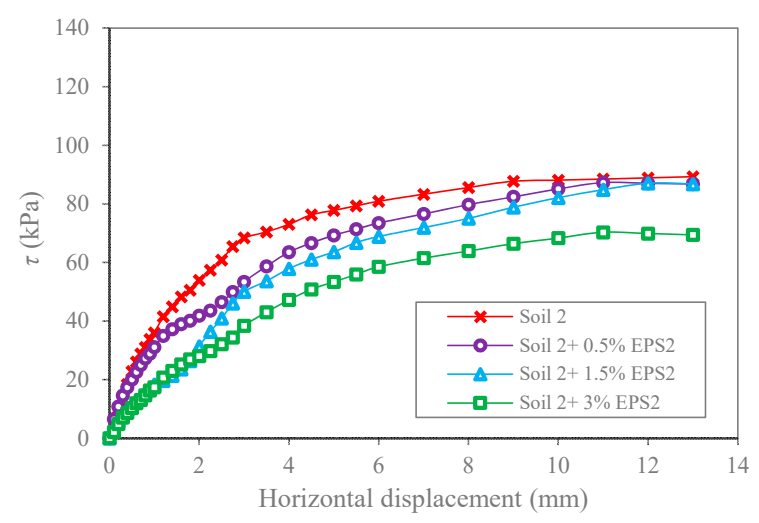

(b) $\sigma_{\mathrm{v}}=100 \mathrm{kPa}$

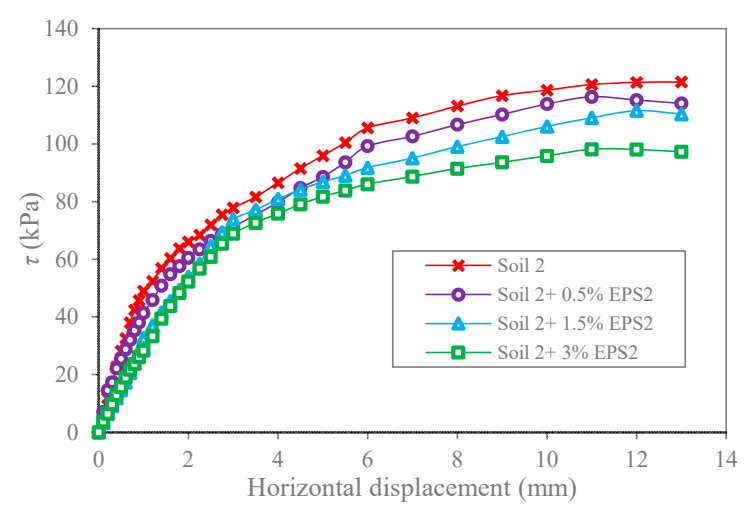

(c) $\sigma_{\mathrm{v}}=150 \mathrm{kPa}$

Figure 12. Shear resistance against horizontal displacement for soil 2-EPS-2 beads mixtures from shearbox tests.

Figures 13-16 show the vertical displacement against horizontal displacement traces for the various clayey sand-EPS beads mixtures. As plotted, negative vertical displacement readings indicate specimen compression. As evident from these figures, the specimen shearing response is significantly affected by EPS content. Compared to the dilative response of the controls (soils 1 and 2), the soil-EPS beads mixtures generally experienced contraction during shearing, and, predictably, greater contraction levels occurred for higher EPS content and for larger applied normal stress. Similar to the consolidation stage behaviour, compared to EPS-1, the specimen compression occurring during shearing for a given soil type and applied normal stress was generally substantially greater for those mixtures containing larger-sized EPS beads (i.e., EPS-2).

Regarding the strength envelopes, these are very likely curved for the studied soil-EPS beads mixtures. For the investigated normal stress range of $\sigma_{\mathrm{v}}=50-150 \mathrm{kPa}$, Figure 17 presents the pairings of cohesion intercept $(c)$ and angle of shearing resistance $(\varphi)$ magnitudes deduced from best-fit lines to the three mobilized peak shear resistance $\left(\tau_{\mathrm{f}}\right)$ results plotted against applied normal stress $\left(\sigma_{\mathrm{v}}\right)$ for each soil-EPS beads mixture. The presented $c-\varphi$ values are simply fitting parameters deduced for the $\tau_{\mathrm{f}}-\sigma_{\mathrm{v}}$ failure line segment over the investigated normal stress range for each soil-EPS beads mixture, so the cohesion intercept magnitude simply derives from the adjustment of a straight line. Apparent reductions in $\varphi$ (and progressive increases in $c$ ) magnitude occur for increasing EPS content, with larger-sized EPS bead (EPS-2) inclusions appearing to produce marginally greater values of $c$ and $\varphi$ for a given soil type and EPS content. 


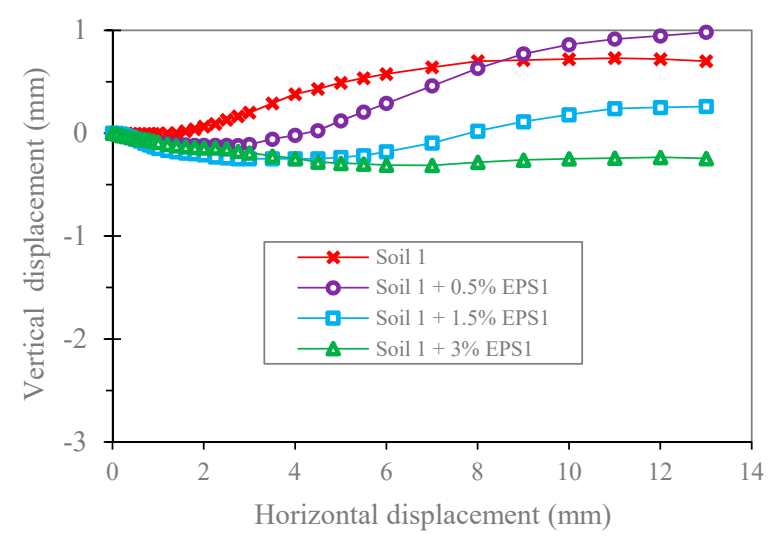

(a) $\sigma_{\mathrm{v}}=50 \mathrm{kPa}$

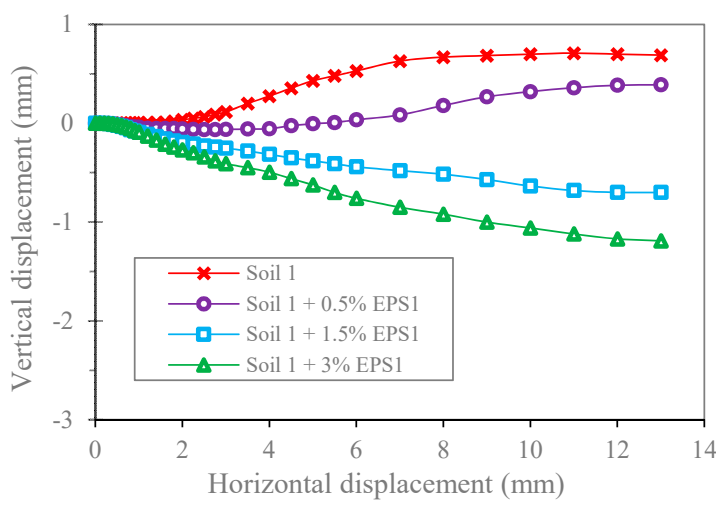

(b) $\sigma_{\mathrm{v}}=100 \mathrm{kPa}$

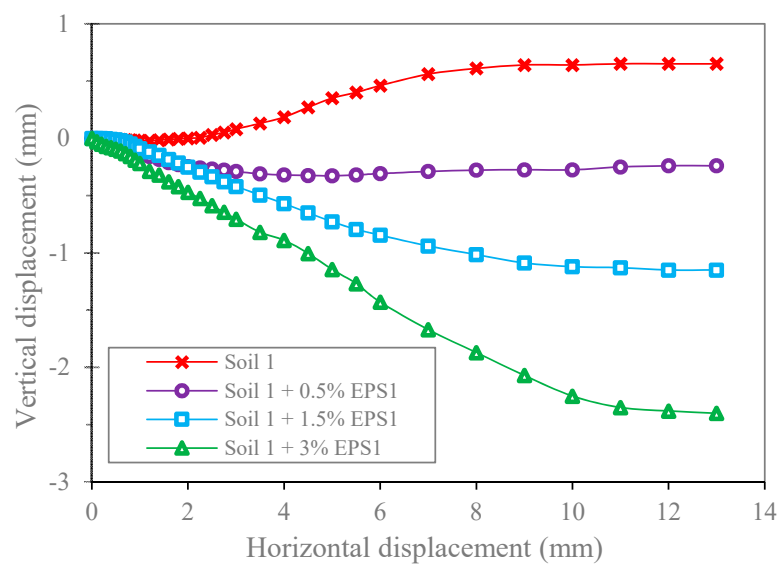

(c) $\sigma_{\mathrm{v}}=150 \mathrm{kPa}$

Figure 13. Vertical against horizontal displacements for soil 1-EPS-1 beads mixtures from shearbox tests.

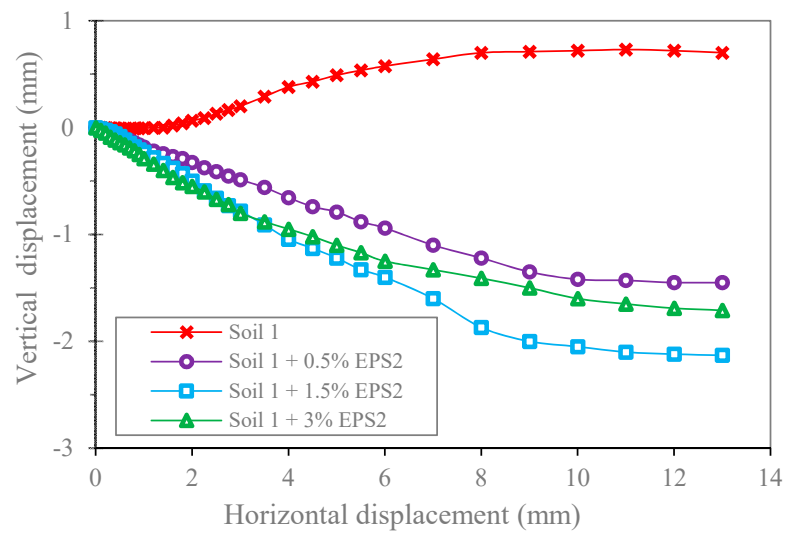

(a) $\sigma_{\mathrm{v}}=50 \mathrm{kPa}$

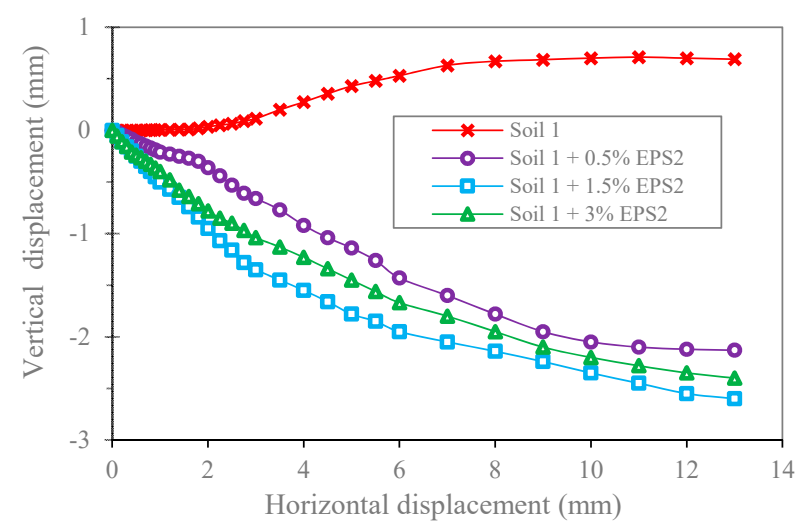

(b) $\sigma_{\mathrm{v}}=100 \mathrm{kPa}$

Figure 14. Cont. 


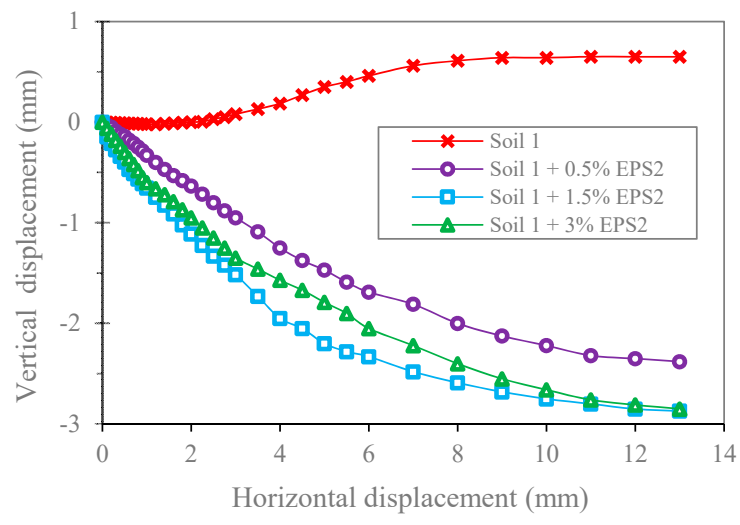

(c) $\sigma_{\mathrm{v}}=150 \mathrm{kPa}$

Figure 14. Vertical against horizontal displacements for soil 1-EPS-2 beads mixtures from shearbox tests.

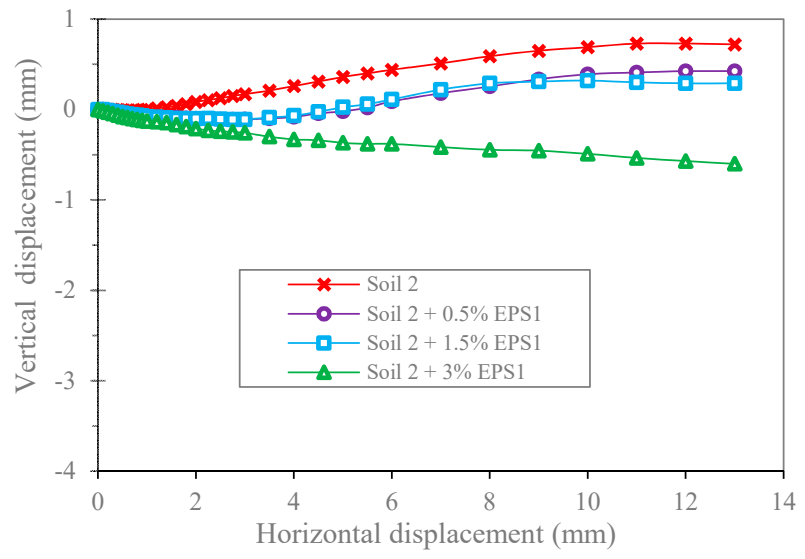

(a) $\sigma_{\mathrm{v}}=50 \mathrm{kPa}$

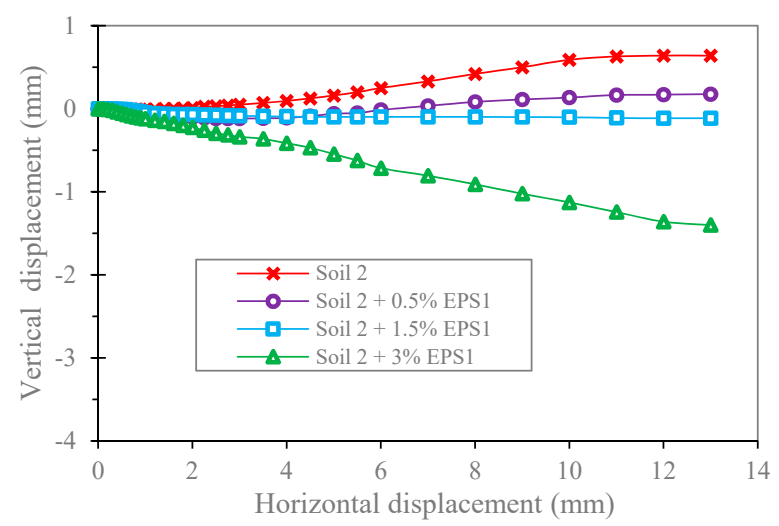

(b) $\sigma_{\mathrm{v}}=100 \mathrm{kPa}$

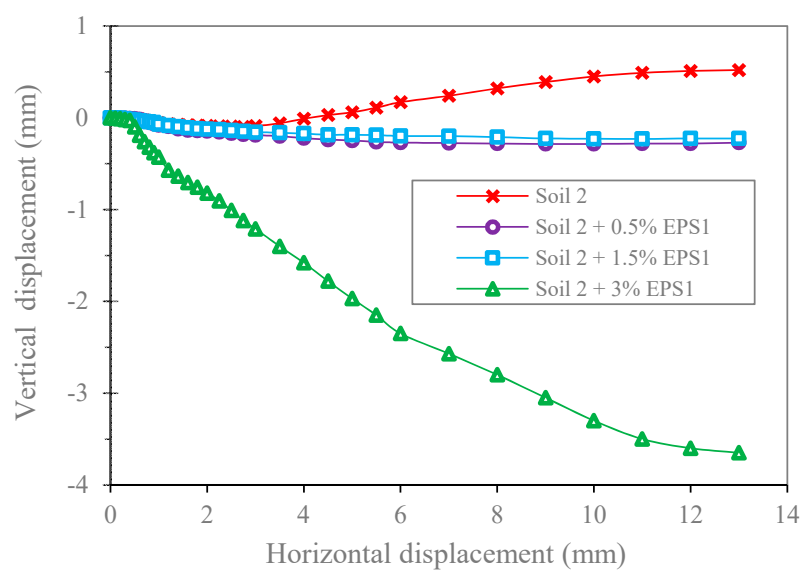

(c) $\sigma_{\mathrm{v}}=150 \mathrm{kPa}$

Figure 15. Vertical against horizontal displacements for soil 2-EPS-1 beads mixtures from shearbox tests. 


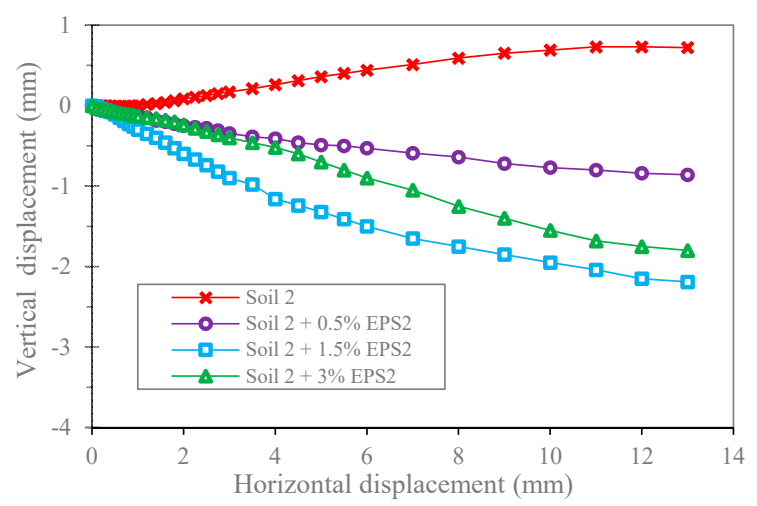

(a) $\sigma_{\mathrm{v}}=50 \mathrm{kPa}$

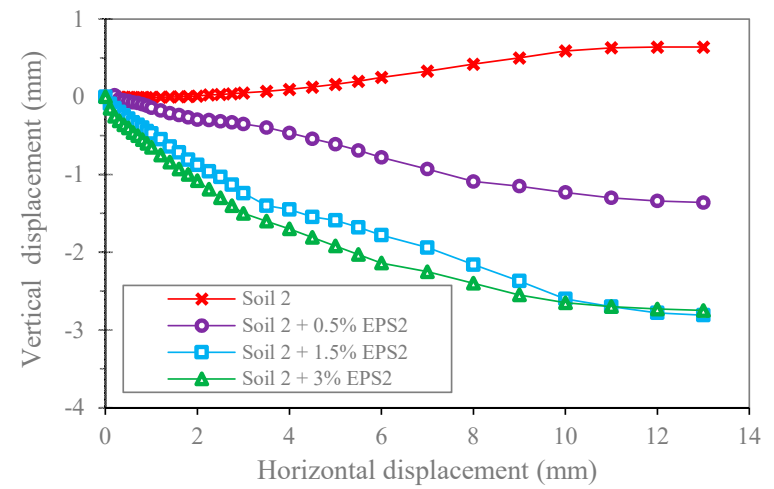

(b) $\sigma_{\mathrm{v}}=100 \mathrm{kPa}$

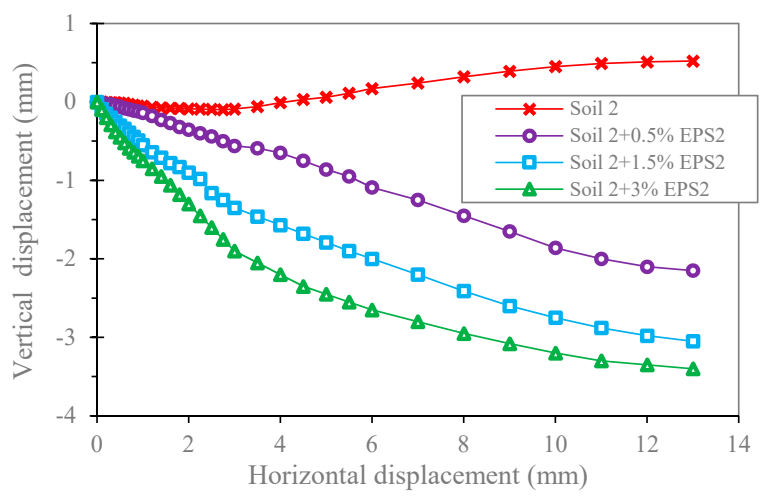

(c) $\sigma_{\mathrm{v}}=150 \mathrm{kPa}$

Figure 16. Vertical against horizontal displacements for soil 2-EPS-2 beads mixtures from shearbox tests.

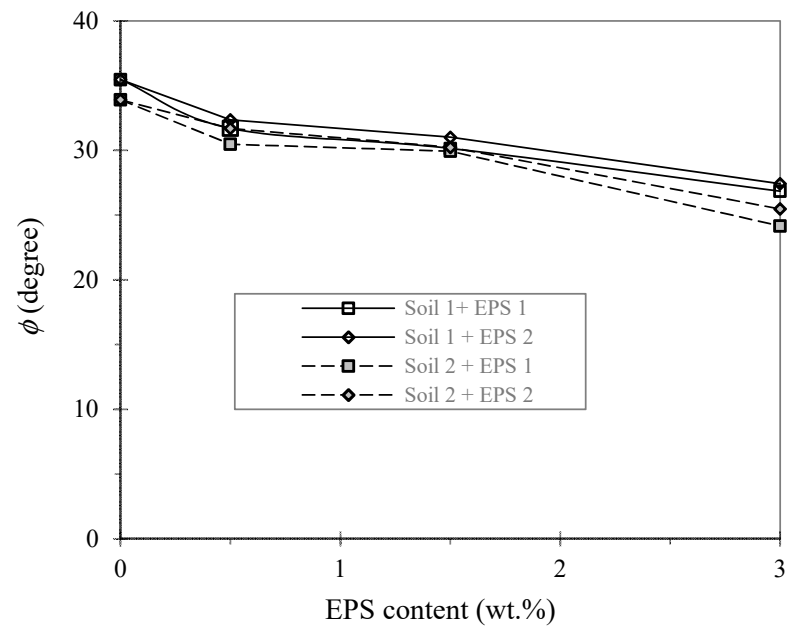

(a) Angle of shearing resistance

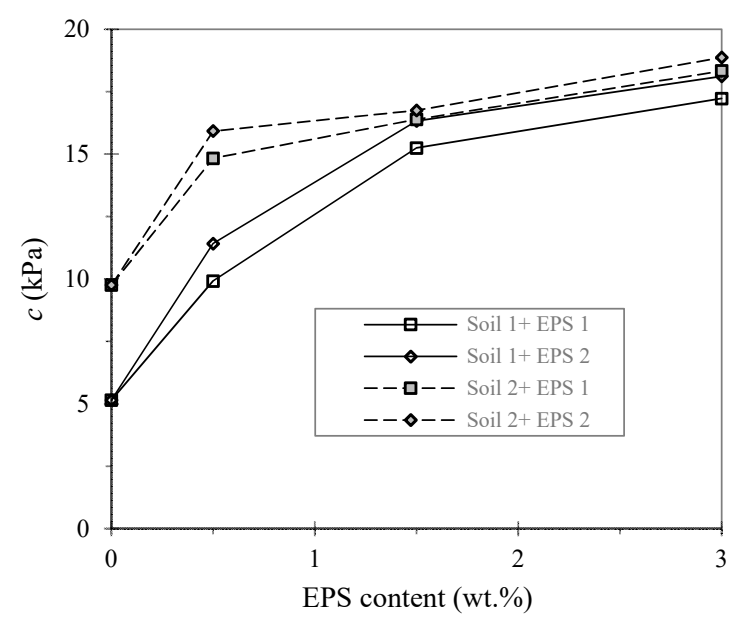

(b) Cohesion intercept

Figure 17. Deduced shear strength parameters for clayey sand-EPS beads mixtures from direct shear testing for $\sigma_{\mathrm{v}}=50-150 \mathrm{kPa}$.

\subsection{Oedometer Results}

Figure 18 presents the variation of the compression index $\left(C_{c}\right)$ with EPS beads content for SP-compacted specimens over the investigated stress range of $\sigma_{\mathrm{v}}=50-400 \mathrm{kPa}$ applied in the oedometer tests. Figures 19 and 20 present the coefficient of consolidation $\left(c_{\mathrm{V}}\right)$ and 
secondary compression index $\left(C_{\alpha}\right)$, deduced from curve-fitting analyses of the recorded specimen strain against elapsed time responses for each maintained load stage.

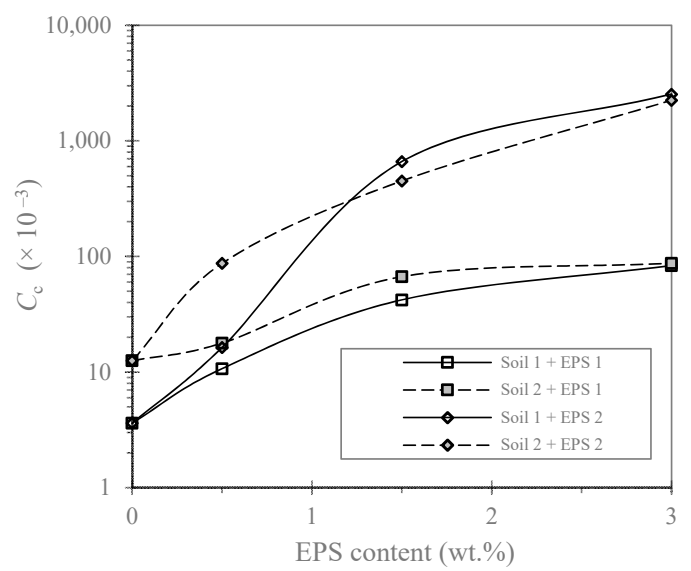

(a) $\sigma_{\mathrm{v}}=50 \mathrm{kPa}$

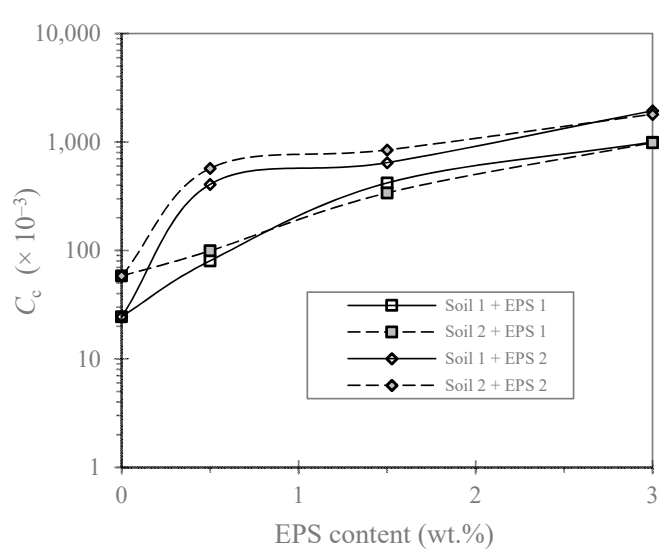

(c) $\sigma_{\mathrm{v}}=200 \mathrm{kPa}$

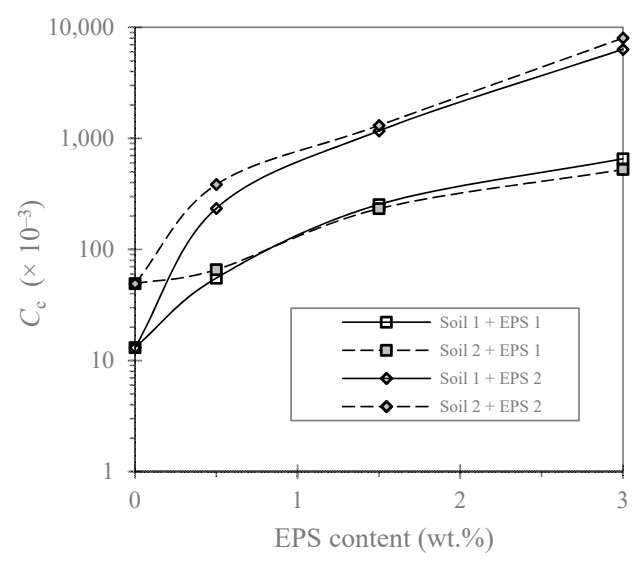

(b) $\sigma_{\mathrm{v}}=100 \mathrm{kPa}$

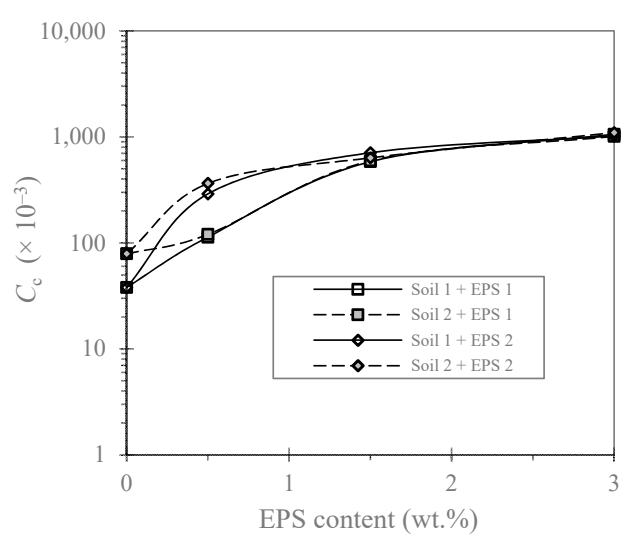

(d) $\sigma_{\mathrm{v}}=400 \mathrm{kPa}$

Figure 18. Variation in compression index with EPS beads content.

Expectedly, with increasing EPS content and especially for larger-sized EPS beads (EPS-2), the magnitude of $C_{\mathrm{c}}$ substantially increases, due to the much greater compressibility of the EPS beads compared to the soil matrix, whereas apparently the computed magnitude of $c_{\mathrm{v}}$ substantially decreases. The latter occurred because, although the time period $t_{50}$ (corresponding to $50 \%$ primary consolidation, as deduced from curve-fitting analysis of the specimen compression against logarithm of elapsed time traces) increased for greater EPS content, significant reductions in the specimen effective drainage length occurred in unison, the net result of which caused substantial reductions in calculated $c_{\mathrm{V}}$ values with increasing EPS content and for greater applied stress levels. Referring to Figure 20, for a given soil, the $C_{\alpha}$ magnitude significantly increases overall with increasing EPS content, especially for larger-sized EPS beads (i.e., EPS-2), which, again, is related to the much greater creep compression of the included EPS beads. 


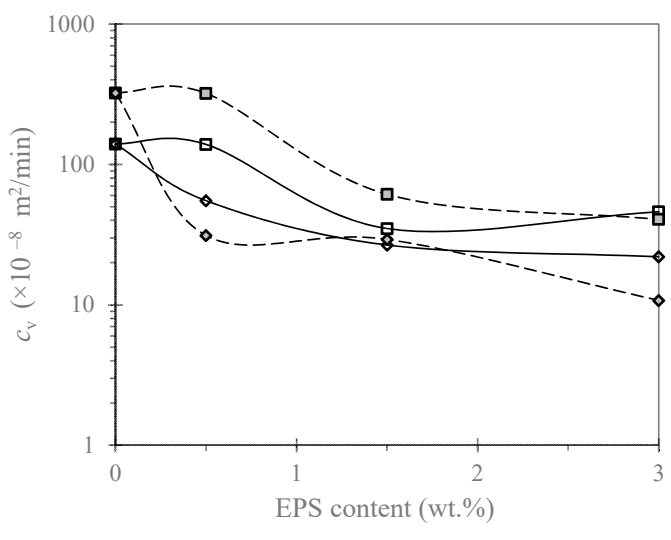

(a) $\sigma_{\mathrm{v}}=50 \mathrm{kPa}$

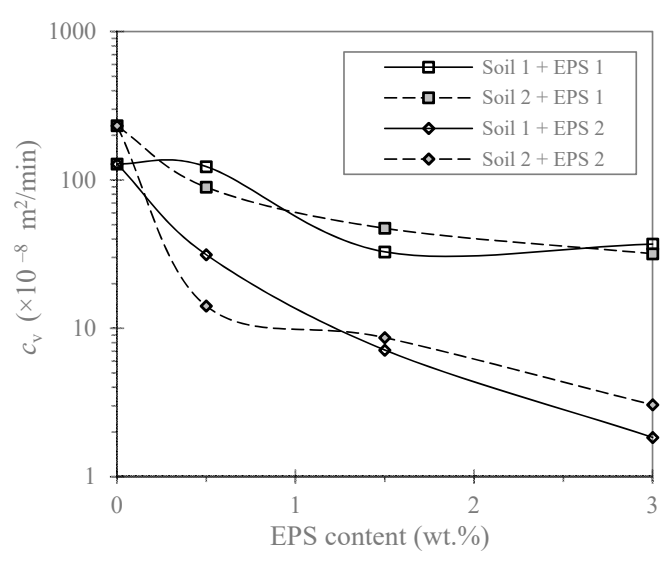

(c) $\sigma_{\mathrm{v}}=200 \mathrm{kPa}$

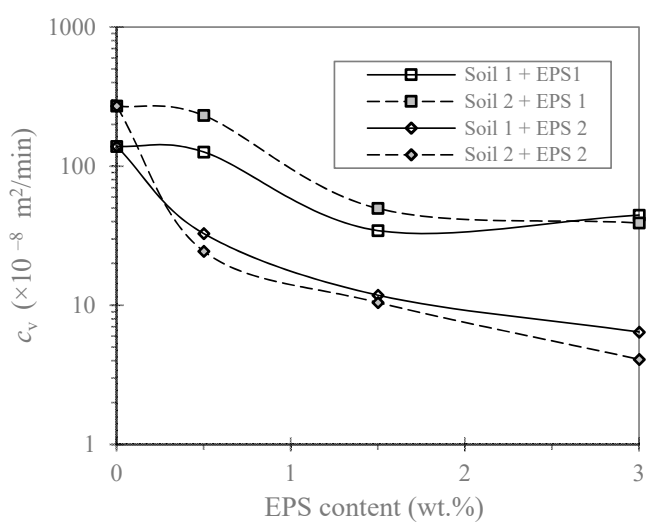

(b) $\sigma_{\mathrm{v}}=100 \mathrm{kPa}$

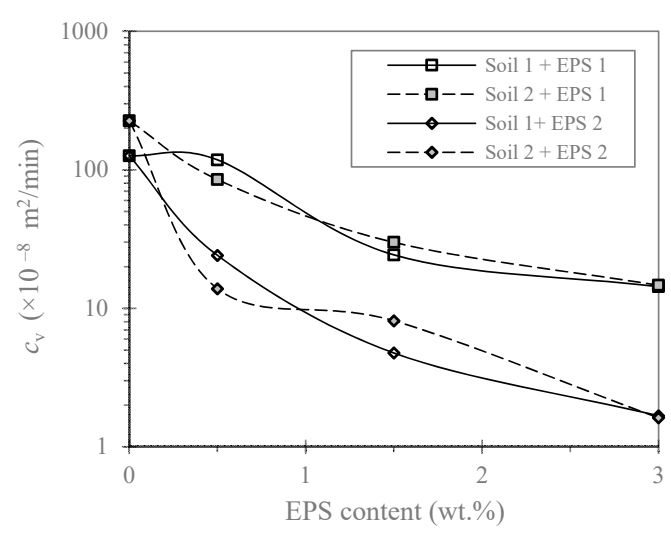

(d) $\sigma_{\mathrm{v}}=400 \mathrm{kPa}$

Figure 19. Apparent variation in coefficient of consolidation with EPS beads content.

\subsection{Permeability Results}

Figure 21 presents the variation of the laboratory-measured permeability coefficient (k) with EPS content for the SP-compacted soil-EPS beads specimens. Overall, compared to the controls (order of $10^{-7} \mathrm{~m} / \mathrm{s}$ ), the $k$ magnitude reduced for $0.5 \mathrm{wt} . \%$ EPS, thereafter increasing in value for 1.5 and $3.0 \mathrm{wt} . \%$ EPS; the latter producing an approximately one order of magnitude increase in the $k$ values relative to the controls ( $0 \mathrm{wt} . \%$ EPS). Expectedly, compared to the finer gradation soil (soil 2-EPS beads mixtures), the soil 1-EPS beads mixtures had substantially greater $k$ values, especially for larger-sized EPS beads (EPS-2). 


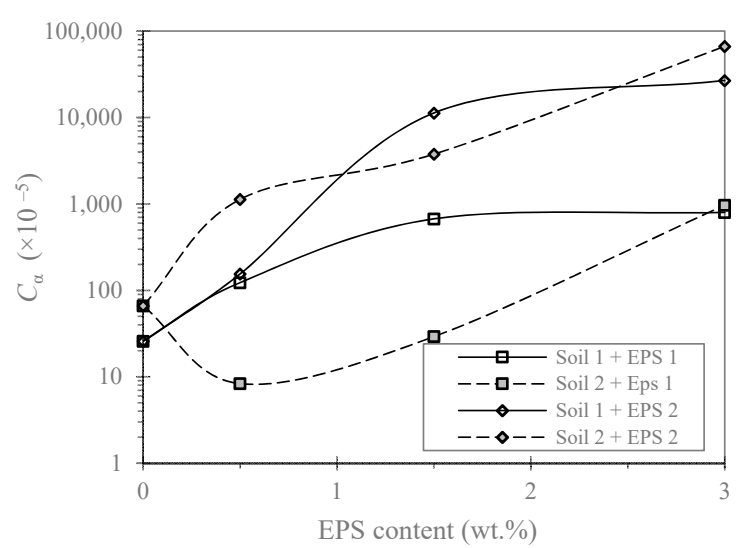

(a) $\sigma_{\mathrm{v}}=50 \mathrm{kPa}$

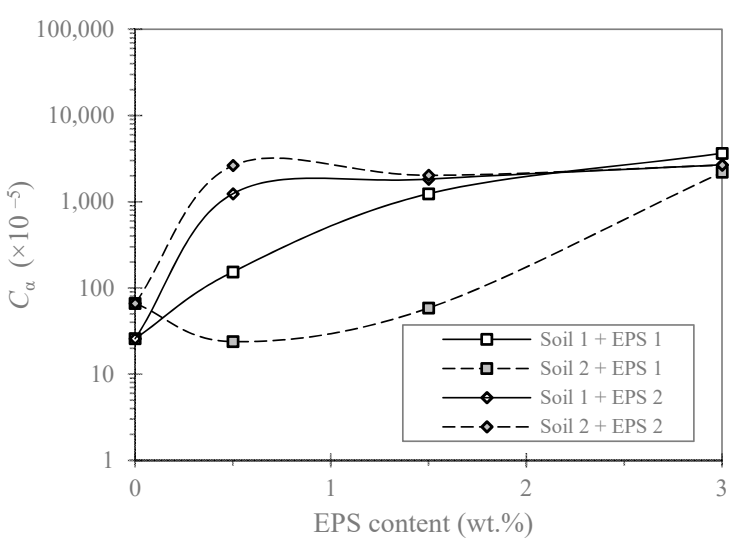

(c) $\sigma_{\mathrm{v}}=200 \mathrm{kPa}$

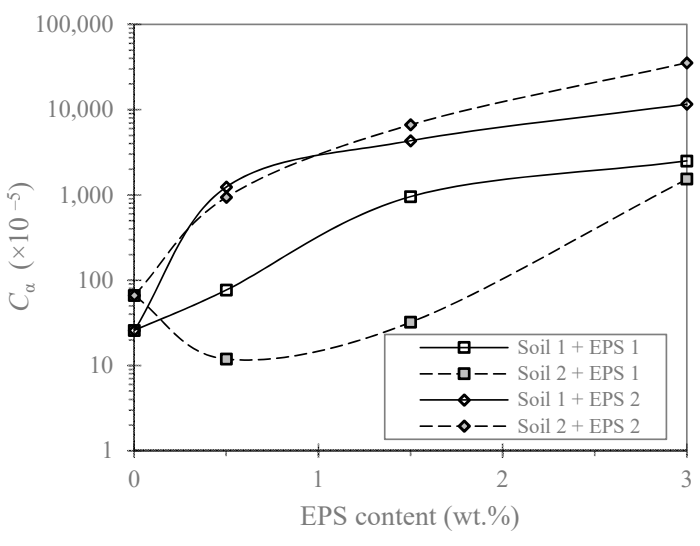

(b) $\sigma_{\mathrm{v}}=100 \mathrm{kPa}$

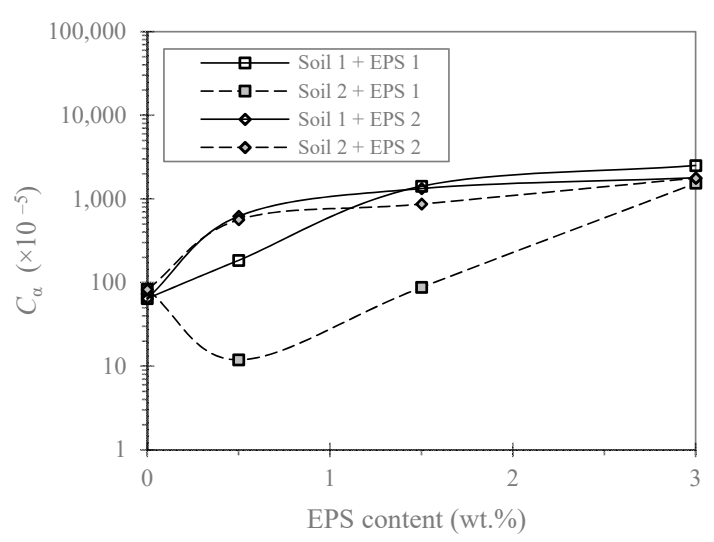

(d) $\sigma_{\mathrm{v}}=400 \mathrm{kPa}$

Figure 20. Variation in secondary compression index with EPS beads content.

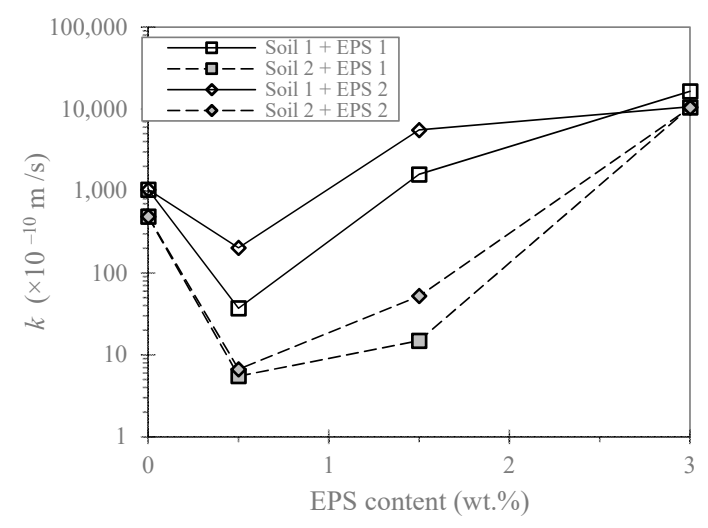

Figure 21. Permeability coefficient against EPS content for investigated clayey sand-EPS beads mixtures.

\section{Environmental Concerns}

Polystyrene (PS) is recyclable if it is composed in block geofoam and, in this form, it is alienable from the soil for geotechnical engineering applications. An obvious question arises, then, as to what is the ecological price of the EPS-sand/clay lightweight fill solution, particularly for uncemented mixtures, where pressed separate EPS beads remain forever among the soil matrix. A part of the total volume of mixed EPS beads can also be swept away during the on-site mixing and construction processes [19]. Below, the environmental 
aspect, which is far-reaching and has not been addressed in previous investigations of EPS-sand/clay mixtures, is elaborated.

From an environmental perspective, plastics, specifically microplastics (MPs), which are generally defined as plastic debris with particle sizes ranging from $0.1 \mu \mathrm{m}$ to $5 \mathrm{~mm}[28,29]$, have emerged as one of the top environmental issues due to their prevalence in, and impacts on, aquatic and terrestrial ecosystems, with evidence for their significant effects on soil biological and ecosystem functions (see review paper by $\mathrm{O}^{\prime} \mathrm{Kell}$ y et al. [30]). To compound the issue, MPs act as a transport vector in soil and groundwater for other potential pollutants, including human pathogens, heavy metals and organic contaminants [31], and they can alter the behaviour of these contaminants, potentially including priority pollutants such as plasticizers and flame retardants that enter in the manufacturing of plastics to enhance their engineering properties [32]. Hence, MPs can become an important conduit for the migration of these contaminants in the subsurface, including potentially significant implications for groundwater quality [30].

Several studies have shown that the migration of MPs through the food chain significantly changes the biological community and, with the decreasing particle size of MPs mainly arising from biodegradation process, leads to the accumulation and transmission of MPs in food chains, reaching humans [33-37]. For instance, investigations by Gaylor et al. [38] and Hodson et al. [39] on the toxicological impact of MPs' ingestion on Eisenia fetida and Lumbricus terrestris earthworm species found that exposure of E. Fetida to higher concentrations of PS MPs $(58 \mu \mathrm{m})$ in soils led to stunted growth and higher mortality rates [40]. Significant changes were observed in plant biomass, elemental tissue composition, root traits, leaf traits and soil microbial activities for Alium fistulosum grown in the presence of various MPs, including PS MPs [41]. The study conducted by Li et al. [42], using fluorescent markers of PS, established the uptake, distribution, transportation and accumulation of $0.2 \mu \mathrm{m}$ sized PS microbeads in an edible plant species (Lactuca sativa). Furthermore, microscopic examination of the shoots' system also revealed the movement of PS microbeads via intercellular spaces of the vascular system, driven along the transpiration stream. Similarly, the roots of $V$. faba exposed to fluorescent MPs of various sizes have shown that the accumulation of these polymers in their roots resulted in reduced growth [43]. These studies have opened a new horizon in the interaction of MPs with plants from the perspective of their fate and transmission in the food chain [30]. It is also patently clear from the above that the ecological price of utilizing EPS-sand/clay mixtures as lightened fill material, leaving myriads of separate EPS beads mixed forever among the soil, is completely unacceptable.

\section{Summary and Conclusions}

The premise of this study was to investigate the merits/limitations, firstly from a geomechanical perspective, of incorporating significant volumes of particulate EPS beads in clayey sand (CS) soil for producing lightened fill material suitable for various engineering applications, investigating the applied stress range of 50 to $400 \mathrm{kPa}$. Based on the presented experimental results for two SP-compacted CS soils admixed with between 0.5 and $3.0 \mathrm{wt} . \%$ (21-73 v.\%) EPS beads, and contrasting with the CS soils themselves, as controls, the following conclusions are drawn:

(a) In terms of dry density, expectedly, the compacted dry density value substantially decreased with increasing EPS beads content, reducing from $2.09 \mathrm{t} / \mathrm{m}^{3}$ for the controls (0 wt.\% EPS) to as low as $0.33 \mathrm{t} / \mathrm{m}^{3}$ for the finer gradation soil with $3 \mathrm{wt} . \%(73 \mathrm{v} . \%)$ of larger-sized EPS beads. As such, compared to conventional geomaterials, clayey sand-EPS beads mixtures seemingly qualify as lightweight fill material.

(b) However, following analyses of the presented CBR, direct shear and oedometer test results, the overall outcome is a substantial mechanical failure in terms of severe immediate, 'consolidation' and creep settlements, particularly for larger sized EPS beads additive, with a drastic decay of the CBR and short- and long-term compressibility parameters, such that even for $0.5 \mathrm{wt} . \%$ ( $21 \mathrm{v} . \%$ ) EPS beads, the clayey sand-EPS beads mixtures are deemed 
unsuitable as load-bearing fill material for the investigated stress range. This would fit with general expectations of using particulate highly compressible material (i.e., EPS beads) having poor geotechnical values as a partial replacement for soil.

For smaller-sized EPS beads at contents $<0.5 \mathrm{wt} . \%$, the uncemented clayey sandEPS beads mixtures may fulfil certain lightened fill requirements for some low applied stress applications $(<50 \mathrm{kPa})$. However, given the demonstrated drastic decay of the most significant geomechanical parameters and the more damming detrimental environmental cost of leaving myriads of separate EPS beads mixed forever among the soil, it is concluded that the approach of adding particulate EPS beads to soil for producing uncemented lightened fill should not be employed in geotechnical engineering practice, such that it does not warrant further attention or investigation from the geotechnical research community.

Author Contributions: Conceptualization, A.G., B.C.O.; methodology, A.G.; validation, A.G., B.C.O.; formal analysis, A.G., B.C.O., M.T.; investigation, M.T.; resources, A.G.; data curation, A.G., M.T.; writing-original draft preparation, B.C.O., M.T., P.A.; writing-review and editing, B.C.O., K.G.I., P.A.; visualization, B.C.O., M.T., P.A.; supervision, A.G.; project administration, A.G.; funding acquisition, A.G. All authors have read and agreed to the published version of the manuscript.

Funding: This research received no external funding.

Conflicts of Interest: The authors declare no conflict of interest.

\section{Nomenclature}

$\begin{array}{ll}c & \text { cohesion intercept } \\ C_{\mathrm{C}} & \text { compression index } \\ C_{\mathrm{U}} & \text { uniformity coefficient } \\ c_{\mathrm{V}} & \text { coefficient of consolidation } \\ C_{\mathrm{Z}} & \text { curvature coefficient } \\ C_{\alpha} & \text { secondary compression index } \\ D_{10} & 10 \% \text { of soil particles finer than this size } \\ D_{30} & 30 \% \text { of soil particles finer than this size } \\ D_{50} & \text { mean particle size } \\ D_{60} & \text { 60\% of soil particles finer than this size } \\ G_{\mathrm{S}(\mathrm{EPS})} & \text { specific gravity of EPS beads } \\ G_{\mathrm{S}} & \text { specific gravity of soil solids } \\ k & \text { permeability coefficient } \\ w & \text { water content } \\ \rho_{\mathrm{d}} & \text { dry density } \\ \rho_{\mathrm{dmax}} & \text { maximum compacted dry density } \\ \gamma_{\mathrm{dmax}} & \text { maximum dry unit weight } \\ \gamma_{\mathrm{dmin}} & \text { minimum dry unit weight } \\ \eta & \text { weight percentage of EPS in dry soil-EPS beads mixture } \\ \varphi & \text { angle of shearing resistance } \\ \sigma_{\mathrm{V}} & \text { applied normal stress } \\ \tau & \text { shear resistance } \\ \tau_{\mathrm{f}} & \text { peak shear resistance } \\ \chi & \text { volume percentage of EPS in dry soil-EPS beads mixture }\end{array}$

\section{References}

1. Oh, S.W.; Lee, J.K.; Kwon, Y.C.; Lee, B.J. Bearing Capacity of Light Weight Soil Using Recycled Styrofoam Beads. In Proceedings of the 12th International Offshore and Polar Engineering Conference, Kitakyushu, Japan, 26-31 May 2002; International Society of Offshore and Polar Engineers: Cupertino, CA, USA, 2002; pp. 670-674.

2. Tsuchida, T.; Kang, M.S. Use of Lightweight Treated Soil Method in Seaport and Airport Construction Projects. In Proceedings of the Nakase Memorial Symposium on Soft Ground Engineering in Coastal Areas, Yokosuka, Japan, 28 November 2002; Tsuchida, T., Watabe, Y., Kang, M.S., Kusakabe, O., Terashi, M., Eds.; Bakelma: Lisse, The Netherlands, 2003; pp. $353-365$. 
3. Gan, C.H.; Tan, S.M. Some Construction Experiences on Soft Soil Using Light Weight Materials. In Proceedings of the 2nd International Conference on Advances in Soft Soil Engineering and Technology, Putrajaya, Malaysia, 2-4 July 2003; Universiti Putra Malaysia Press: Serdang Selangor Darul Ehsan, Malaysia, 2003; pp. 609-616.

4. Tsuchida, T.; Egashira, K. The Lightweight Treated Soil Method-New Geomaterials for Soft Ground Engineering in Coastal Areas; Balkema: Liden, The Netherlands, 2004.

5. Aabøe, R.; Frydenlund, T.E. 40 Years of Experience with the Use of EPS Geofoam Blocks in Road Construction. In Proceedings of the 4th International Conference Geofoam Blocks in Construction Applications (EPS 2011), Lillestrøm, Norway, 6-8 June 2011.

6. Stark, T.D.; Arellano, D.; Horvath, J.S.; Leshchinsky, D. Geofoam Applications in the Design and Construction of Highway Embankments; NCHRP Web Document 65 (Project 24-11); Transportation Research Board: Washington, DC, USA, 2004.

7. Soltani, A.; Deng, A.; Taheri, A.; O'Kelly, B.C. Engineering reactive clay systems by ground rubber replacement and polyacrylamide treatment. Polymers 2019, 11, 1675. [CrossRef] [PubMed]

8. Shahrokhi-Shahraki, R.; Kwon, P.S.; Park, J.; O'Kelly, B.C.; Rezania, S. BTEX and heavy metals removal using pulverized waste tires in engineered fill materials. Chemosphere 2020, 242, 125281. [CrossRef]

9. Soltani, A.; Taheri, A.; Deng, A.; O'Kelly, B.C. Improved geotechnical behavior of an expansive soil amended with tire-derived aggregates having different gradations. Minerals 2020, 10, 923. [CrossRef]

10. Ghadr, S.; Samadzadeh, A.; Bahadori, H.; O'Kelly, B.C.; Assadi-Langroudi, A. Liquefaction resistance of silty sand with ground rubber additive. Int. J. Geomech. 2021, 21, 04021076. [CrossRef]

11. Vaslestad, J.; Bartlett, S.F.; Aabøe, R.; Burkart, H.; Ahmed, T.; Arellano, D. Bridge Foundations Supported by EPS Geofoam Embankments on Soft Soil. In Proceedings of the 5th International Conference on Geofoam Blocks in Construction Applications (EPS 2018), Kyrenia, Cyprus, 9-11 May 2018; Arellano, D., Özer, A.T., Bartlett, S.F., Vaslestad, J., Eds.; Springer: Cham, Switzerland, 2019; pp. 281-294. [CrossRef]

12. Bartlett, S.F.; Lingwall, B.N.; Vaslestad, J. Methods of protecting buried pipelines and culverts in transportation infrastructure using EPS geofoam. Geotext. Geomembr. 2015, 43, 450-461. [CrossRef]

13. Maleska, T.; Nowacka, J.; Beben, D. Application of EPS geofoam to a soil-steel bridge to reduce seismic excitations. Geosciences 2019, 9, 448. [CrossRef]

14. Abdullah, M.; Huat, B.B.K.; Kamaruddin, R.; Ali, A.K.; Duraisamy, Y. Design and performance of EPS footing for lightweight farm structure on peat soil. Am. J. Appl. Sci. 2007, 4, 484-490. [CrossRef]

15. Aminu, I.; Asadi, A.; O’Kelly, B.C.; Huat, B.B.K.; Reul, O. Ultralightweight foundation system for peaty ground. Environ. Geotech. 2021. [CrossRef]

16. Deng, A.; Xiao, Y. Measuring and modeling proportion-dependent stress-strain behavior of EPS-sand mixture. Int. J. Geomech. 2010, 10, 214-222. [CrossRef]

17. Edinçliler, A.; Özer, A.T. Effects of EPS bead inclusions on stress-strain behaviour of sand. Geosynth. Int. 2014, 21, 89-102. [CrossRef]

18. Liu, H.L.; Deng, A.; Chu, J. Effect of different mixing ratios of polystyrene pre-puff beads and cement on the mechanical behaviour of lightweight fill. Geotext. Geomembr. 2006, 24, 331-338. [CrossRef]

19. Satoh, T.; Tsuchida, T.; Mitsukuri, K.; Hong, Z. Field placing test of lightweight treated soil under seawater in Kumamoto port. Soils Found. 2001, 41, 145-154. [CrossRef]

20. Tsuchida, T.; Porbaha, A.; Yamane, N. Development of a geomaterial from dredged bay mud. J. Mater. Civ. Eng. 2001, 13, 152-160. [CrossRef]

21. Yoonz, G.L.; Jeon, S.S.; Kim, B.T. Mechanical characteristics of light-weighted soils using dredged materials. Mar. Georesource Geotechnol. 2004, 22, 215-229. [CrossRef]

22. Rocco, N.T. Characterization of Expanded Polystyrene (EPS) and Cohesive Soil Mixtures. Ph.D. Thesis, Missouri University of Science and Technology, Rolla, MI, USA, 2012.

23. ASTM C128. Standard Test Method for Relative Density (Specific Gravity) and Absorption of Fine Aggregate; ASTM International: West Conshohocken, PA, USA, 2015.

24. ASTM D698. Standard Test Methods for Laboratory Compaction Characteristics of Soil Using Standard Effort (12,400 ft-lbf/ft3 (600 $\left.\mathrm{kN}-\mathrm{m} / \mathrm{m}^{3}\right)$ ); ASTM International: West Conshohocken, PA, USA, 2012.

25. ASTM D1883. Standard Test Methods for CBR (California Bearing Ratio) of Laboratory-Compacted Soils; ASTM International: West Conshohocken, PA, USA, 2016.

26. ASTM D3080. Standard Test Methods for Direct Shear Test of Soils under Consolidated-Drained Conditions; ASTM International: West Conshohocken, PA, USA, 2001.

27. ASTM D2435. Standard Test Method for One-Dimensional Consolidation Properties of Soils Using Incremental Loading; ASTM International: West Conshohocken, PA, USA, 2001.

28. Thompson, R.C.; Olsen, Y.; Mitchell, R.P.; Davis, A.; Rowland, S.J.; John, A.W.G.; McGonigle, D.; Russell, A.E. Lost at sea: Where is all the plastic? Science 2004, 304, 838. [CrossRef]

29. Galgani, F.; Hanke, G.; Werner, S.; De Vrees, L. Marine litter within the European Marine Strategy Framework Directive. ICES J. Mar. Sci. 2013, 70, 1055-1064. [CrossRef]

30. O'Kelly, B.C.; El-Zein, A.; Liu, X.; Patel, A.; Fei, X.; Sharma, S.; Mohammad, A.; Goli, V.S.N.S.; Wang, J.J.; Li, D.; et al. Microplastics in soils: An environmental geotechnics perspective. Environ. Geotech. 2021. [CrossRef] 
31. Qi, R.; Jones, D.L.; Li, Z.; Liu, Q.; Yan, C. Behavior of microplastics and plastic film residues in the soil environment: A critical review. Sci. Total Environ. 2020, 703, 134722. [CrossRef] [PubMed]

32. Van Praagh, M.; Hartman, C.; Brandmyr, E. Microplastics in Landfill Leachates in the Nordic Countries; TemaNord NV-2018:557; Nordisk Ministerråd: Copenhagen, Denmark, 2018. [CrossRef]

33. Kiyama, Y.; Miyahara, K.; Ohshima, Y. Active uptake of artificial particles in the nematode Caenorhabditis Elegans. J Exp. Biol. 2012, 215, 1178-1183. [CrossRef]

34. Von Moos, N.; Burkhardt-Holm, P.; Köhler, A. Uptake and effects of microplastics on cells and tissue of the blue mussel Mytilus edulis L. after an experimental exposure. Environ. Sci. Technol. 2012, 46, 11327-11335. [CrossRef]

35. Farrell, P.; Nelson, K. Trophic level transfer of microplastic: Mytilus edulis (L.) to Carcinus maenas (L.). Environ. Pollut. 2013, 177, 1-3. [CrossRef]

36. Wright, S.L.; Rowe, D.; Thompson, R.C.; Galloway, T.S. Microplastic ingestion decreases energy reserves in marine worms. Curr. Biol. 2013, 23, 1031-1033. [CrossRef] [PubMed]

37. Wright, S.L.; Thompson, R.C.; Galloway, T.S. The physical impacts of microplastics on marine organisms: A review. Environ. Pollut. 2013, 178, 483-492. [CrossRef] [PubMed]

38. Gaylor, M.O.; Harvey, E.; Hale, R.C. Polybrominated diphenyl ether (PBDE) accumulation by earthworms (Eisenia fetida) exposed tobiosolids-, polyurethane foam microparticle-, and Penta-BDE-amended soils. Environ. Sci. Technol. 2013, 47, 13831-13839. [CrossRef] [PubMed]

39. Hodson, M.E.; Duffus-Hodson, C.A.; Clark, A.; Prendergast-Miller, M.T.; Thorpe, K.L. Plastic bag derived-microplastics as a vector for metal exposure in terrestrial invertebrates. Environ. Sci. Technol. 2017, 51, 4714-4721. [CrossRef] [PubMed]

40. Cao, D.; Wang, X.; Luo, X.; Liu, G.; Zheng, H. Effects of polystyrene microplastics on the fitness of earthworms in an agricultural soil. IOP Conf. Ser. Earth Environ. Sci. 2017, 61, 012148. [CrossRef]

41. de Souza Machado, A.A.; Lau, C.W.; Kloas, W.; Bergmann, J.; Bachelier, J.B.; Faltin, E.; Becker, R.; Görlich, A.S.; Rillig, M.C. Microplastics can change soil properties and affect plant performance. Environ. Sci. Technol. 2019, 53, 6044-6052. [CrossRef]

42. Li, L.; Zhou, Q.; Yin, N.; Tu, C.; Luo, Y. Uptake and accumulation of microplastics in an edible plant. Kexue Tongbao/Chin. Sci. Bull. 2019, 64, 928-934. [CrossRef]

43. Jiang, X.; Chen, H.; Liao, Y.; Ye, Z.; Li, M.; Klobučar, G. Ecotoxicity and genotoxicity of polystyrene microplastics on higher plant Vicia faba. Environ. Pollut. 2019, 250, 831-838. [CrossRef] [PubMed] 